\title{
Chemical composition and antimicrobial activity of Myrtus communis essential oils from Algeria
}

\author{
YACINE MOHAMADI ${ }^{1}$, TAKIA LOGRADA ${ }^{1}$, MESSAOUD RAMDANI ${ }^{1, \bullet}$, GILLES FIGUEREDO ${ }^{2}$, \\ PIERRE CHALARD ${ }^{3}$ \\ ${ }^{1}$ Laboratory of Natural Resource Valorization, Faculty of Life and Natural Sciences, Ferhat Abbas University Setif-1. 19000 Setif, Algeria. \\ vemail: ramdanimessaoud@yahoo.com \\ ${ }^{2}$ LEXVA Analytique. 460 Rue Du Montant, 63110 Beaumont, France \\ ${ }^{3}$ Université Clermont Auvergne. CNRS, SIGMA Clermont, ICCF, F-63000 Clermont-Ferrand, France
}

Manuscript received: 5 December 2020. Revision accepted: 20 January 2021.

\begin{abstract}
Mohamadi Y, Lograda T, Ramdani M, Figueredo G, Chalard P. 2021. Chemical composition and antimicrobial activity of Myrtus communis essential oils from Algeria. Biodiversitas 22: 933-946. The objectives of this study were to determine the chemical composition and the antibacterial activities of Myrtus communis essential oils. The aerial parts of the myrtle were collected from nineteen localities of the Algerian coast, and subjected to hydrodistillation. The chemical composition of essential oils was analyzed using gas chromatography coupled with mass spectrometry (GC/MS). The antibacterial activity was evaluated by the disk diffusion method against ten bacterial species. Essential oils of $M$. communis was pale yellow oils, very fragrant, with an average yield of $0.68 \pm$ $0.6 \%$. Forty-six compounds were identified, representing an average of $99.17 \pm 0.6 \%$ of total oils. The $\alpha$-pinene was the most abundant component in the essential oils of all populations studied, with a mean of $50.1 \pm 10.3 \%$, followed by 1,8 -cineole $(22.27 \pm 4.32 \%)$, limonene $(5.16 \pm 2.67 \%)$, linalool $(3.79 \pm 2.97 \%)$, $\alpha$-terpineol $(2.75 \pm 1.12 \%)$, geranyl acetate $(1.95 \pm 0.7 \%)$ and methyl eugenol $(1.40 \pm$ 0.98\%). Myrtenyl acetate was only observed in four populations with significant levels (from 10.66 to 20.94\%). Six chemotypes have been identified in these oils. The $\alpha$-pinene - 1,8-cineole-limonene chemotype was found in the majority of populations. The chemotype of $\alpha$-pinene-1,8-cineole- $\alpha$-terphenyl acetate characterizes the Oued El-Aneb population. The $\alpha$-pinene-neryl formate-limonene chemotype is observed in the Honaïn population. The remaining populations are characterized by myrtenyl acetate. The essential oils of M. communis were effective against Staphylococcus aureus ATCC 25923, Salmonella enterica ATCC35659, Proteus mirabilis, and Escherichia coli ATCC 25922; however, no significant effect was observed on Klebsiella pneumonia ATCC 700603 and Serratia liquefaciens.
\end{abstract}

Keywords: Algeria, antibacterial activity, essential oil, chemotypes, bioactive molecule, Myrtus communis

\section{INTRODUCTION}

The myrtle (Myrtus communis L.) is an aromatic evergreen shrub of the Myrtaceae family, which grows naturally in the scrubland along the coasts with a Mediterranean climate (Quezel and Santa 1963; Migliore et al. 2012); in Brazil (Salvagnini et al. 2008; Thornill et al. 2015) and India (Sumbul et al. 2011).

Myrtus communis has many therapeutic properties and widely used in the cosmetics and food industry. Previous studies have confirmed that $M$. communis has antiinflammatory properties (Rossi et al. 2009; Hosseinzadeh et al. 2011; Amira et al. 2012), antiseptics (Amensour et al. 2010), antibacterial and antifungal (Messaoud et al. 2011; Zomorodian et al. 2013; Cannas et al. 2013; Bouzabata 2015). It also has activities as anti-protozoan (Deriu et al. 2007; Belmimoun et al. 2016), antiparasitic and antispasmodic (Satrani et al. 2006), anti-genotoxic, antimutagen (Hayder et al. 2003), antioxidants (Mimica-Dukić et al. 2010; Aidi et al. 2010; Cherrat et al. 2014), hypoglycemic (Onal et al. 2005), and other medicinal uses (Sumbul et al. 2011; Alipour et al. 2014; Franceschini 2016; Sissay and Gashaw 2017; Hennia et al. 2018).
The chemical composition of myrtle oil was varied due to several environmental factors (Gardeli et al. 2008; Barboni et al. 2010) and genetic (Messaoud et al. 2007; Sacchetti et al. 2007; Shoshtari et al. 2017). M. communis essential oils from Algeria contain $\alpha$-pinene and 1,8cineole as the main components (Table 1). The other major components were $\alpha$-pinene, 1,8-cineole, limonene, myrtenyl acetate, methyl eugenol, and linalool with different values depending on the harvest area. The level of $\alpha$-pinene in Corsica populations is 66\% (Bradesi et al. 1997), whereas it is absent in Cyprus populations (Akin et al. 2010). The 1,8-cineole in the Tunisian population is 2.3\% (Bettaieb et al., 2016), while the Moroccan population is $64.9 \%$ (Fadil and al. 2017). The Italian population contains $44.2 \%$ limonene (Tuberoso et al. 2006), but it is absent in the Greek populations (Gardeli et al. 2008).

The myrtenyl acetate contains in myrtle oils from several countries, such as Portugal (Pereira et al. 2009), Spain (Boelens and Jimenez 1991, 1992), Albania (Asllani 2000), Montenegro (Mimica dukić et al. 2010), Greece (Ghardeli et al. 2008), Iran (Shahbazian et al. 2018), Morocco (Fadil et al. 2017; Cherrat et al. 2014; Satrani et al. 2006) and Tunisia (Messaoud et al. 2011; Traboulsi et 
al. 2002). The highest level of myrtenyl acetate (61.1\%) is observed in myrtle oil from Morocco (Fadil et al. 2017), while its presence in Algeria is only reported in myrtle oils from the population of Ain Defla at the level of $38.7 \%$ (Touaïbia 2016). Anwar et al. (2017) identified at least 12 chemotypes in $M$. communis based on its chemical composition variability. The $\alpha$-pinene, 1,8-cineole chemotype is the most frequently found in nature. Bradesi et al. (1997) separated myrtle oils into two groups based on the presence or absence of myrtenyl acetate.

Several authors have studied the antibacterial activity of myrtle oils. Ebrahimabadi et al. (2016) stated that the presence of $\alpha$-pinene and 1,8-cineole in the oil contributes to antibacterial activities. Cox et al. (2001) suggest that the presence of $\beta$-pinene and limonene, while Carson and Riley (1995) proposed that linalool is responsible for antibacterial activity. The essential oils of M. communis from Algeria showed moderate antibacterial activity against twenty bacterial strains (Barhouchi et al. 2016). The Moroccan oil shows potent inhibition against E. coli and weak against $S$. aureus (Sadiki et al. 2014).

This work aimed to study the chemical composition of the essential oils of Myrtus communis from Algeria, identify the chemotypes, and determine the antibacterial activities of these oils.

\section{MATERIALS AND METHODS}

\section{Plant material}

Myrtus communis is a shrub easily recognizable by its beautiful white flowers in summer and its bluish fruits in winter. This plant grows on almost the entire Mediterranean coast in Algeria. Samples of M. communis were collected in the flowering stage (June 2016) from 19 localities in northern Algeria (Figure 1; Table 2). Reference specimens were deposited in the herbarium of the Laboratory of Natural Resources Valorisation, Ferhat Abbas University Setif-1, Algeria.

\section{The essential oil extraction}

The air-dried materials were subjected to hydrodistillation for $3 \mathrm{~h}$ using a Clevenger apparatus type. The oil was collected and dried over anhydrous sodium sulfate and stored in screw-capped glass vials in a refrigerator at $4-5^{\circ} \mathrm{C}$ before analysis. The following formula calculated the yield of essential oil:

Yield in essential oil $(\%)=\frac{\text { Weight of the essential oil }}{\text { Weight of the plant used }} \times 100$

Table 1. Chemical composition of essential oils of Myrtus communis from Algeria

\begin{tabular}{|c|c|c|c|c|c|c|c|c|c|c|c|c|c|c|c|c|c|}
\hline Localities & 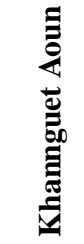 & 总 & 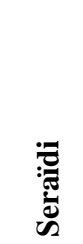 & 恶 & صี & $\begin{array}{l}\frac{\pi}{8} \\
\frac{y}{n}\end{array}$ & 营 & 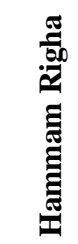 & 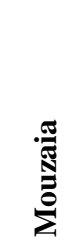 & 苞 & 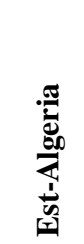 & 㤣 & 氖 & 湾 & $\begin{array}{l}\frac{\pi}{\pi \nu} \\
\vdots \\
\vdots\end{array}$ & 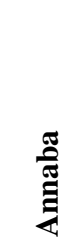 & 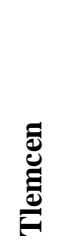 \\
\hline References & & $\mathbf{A}$ & & B & $\mathbf{C}$ & & & D & & $\mathbf{E}$ & $\mathbf{F}$ & & i & H & I & $\mathbf{J}$ & $\mathbf{K}$ \\
\hline Isobutyl isobutyrate & 2.4 & 2.9 & 1.9 & 0.0 & 0.3 & 0.5 & 0.1 & 0.6 & 1.6 & 0.3 & 0.0 & 0.5 & 1.2 & 0.0 & 3.0 & 0.2 & 0.0 \\
\hline$\alpha$-pinene & 49.1 & 47.7 & 57.3 & 46.9 & 44.6 & 47.9 & 41.9 & 34.2 & 33.6 & 39.3 & 45.4 & 37.3 & 24.7 & 54.1 & 13.7 & 55.0 & 31.3 \\
\hline$\rho$-cymene & 0.6 & 1.0 & 0.6 & 0.6 & 0.3 & 1.2 & 1.3 & 0.4 & 0.8 & 0.0 & 0.5 & 0.6 & 0.6 & 0.7 & 0.0 & 0.0 & 0.9 \\
\hline Limonene & 6.7 & 8.2 & 5.5 & 0.0 & 3.7 & 4.2 & 6.2 & 4.6 & 23.6 & 0.1 & 8.4 & 17.7 & 15.4 & 2.0 & 0.0 & 13.4 & 11.1 \\
\hline 1.8-cineole & 25.0 & 24.4 & 18.7 & 25.2 & 25.5 & 23.5 & 27.8 & 13.0 & 7.2 & 33.3 & 35.7 & 17.6 & 17.3 & 26.5 & 12.7 & 20.0 & 36.8 \\
\hline Linalool & 2.6 & 2.5 & 2.9 & 5.6 & 0.0 & 2.9 & 1.5 & 14.8 & 10.0 & 6.5 & 0.0 & 10.7 & 24.6 & 2.4 & 7.0 & 1.4 & 3.6 \\
\hline$\beta$-linalool & 0.0 & 0.0 & 0.0 & 0.0 & 2.1 & 0.0 & 0.0 & 0.0 & 0.0 & 0.0 & 1.9 & 0.0 & 0.0 & 0.0 & 0.0 & 0.0 & 0.0 \\
\hline Terpinene-4-ol & 0.3 & 0.3 & 0.3 & 0.0 & 1.3 & 0.3 & 0.2 & 0.2 & 0.2 & 0.3 & 0.4 & 0.3 & 0.2 & 0.0 & 0.2 & 0.0 & 0.3 \\
\hline$\alpha$-terpineol & 3.1 & 3.2 & 3.4 & 1.3 & 2.2 & 2.7 & 2.7 & 3.8 & 2.0 & 3.4 & 0.0 & 3.9 & 3.5 & 2.3 & 1.8 & 0.0 & 3.6 \\
\hline Myrtenol & 0.0 & 0.0 & 0.0 & 0.0 & 0.0 & 0.0 & 0.0 & 0.0 & 0.0 & 0.0 & 0.0 & 0.0 & 0.0 & 0.0 & 3.5 & 0.0 & 0.0 \\
\hline Geraniol & 0.5 & 0.5 & 0.2 & 0.0 & 0.4 & 0.0 & 0.0 & 0.0 & 0.0 & 1.2 & 0.0 & 0.6 & 1.3 & 0.6 & 0.0 & 0.3 & 0.5 \\
\hline Linalyl acetate & 0.0 & 0.0 & 0.0 & 4.2 & 0.4 & 1.4 & 1.6 & 9.1 & 5.9 & 0.0 & 0.0 & 0.7 & 1.3 & 0.4 & 2.5 & 0.4 & 0.0 \\
\hline Myrtenyl acetate & 0.0 & 0.0 & 0.0 & 0.0 & 0.0 & 0.0 & 0.0 & 0.0 & 0.0 & 0.0 & 0.1 & 0.0 & 0.0 & 0.0 & 38.7 & 0.0 & 0.0 \\
\hline$\alpha$-terpenyl acetate & 0.0 & 0.0 & 0.0 & 1.1 & 0.7 & 0.7 & 1.6 & 1.1 & 0.5 & 0.0 & 0.0 & 0.6 & 0.2 & 0.4 & 0.0 & 0.0 & 0.0 \\
\hline Geranyl acetate & 2.4 & 2.9 & 1.9 & 4.2 & 2.2 & 3.3 & 3.3 & 2.9 & 2.7 & 3.0 & 0.0 & 2.0 & 1.9 & 2.3 & 0.4 & 2.0 & 2.9 \\
\hline Neryl acetate & 0.0 & 0.0 & 0.0 & 0.0 & 0.0 & 0.0 & 0.0 & 0.0 & 0.0 & 0.0 & 0.0 & 0.1 & 0.3 & 0.0 & 2.0 & 0.2 & 0.0 \\
\hline Methyl eugenol & 1.3 & 1.1 & 1.3 & 0.5 & 2.2 & 1.0 & 1.1 & 1.8 & 1.9 & 0.0 & 0.0 & 1.3 & 1.8 & 1.4 & 0.0 & 0.6 & 2.2 \\
\hline$\beta$-caryophyllene-Z & 0.6 & 0.5 & 0.6 & 0.0 & 0.0 & 0.5 & 0.9 & 0.6 & 0.3 & 0.0 & 0.0 & 0.0 & 0.0 & 0.0 & 0.0 & 0.0 & 0.0 \\
\hline
\end{tabular}

Note: A. Bouzabata et al. (2010); B. Brada et al. (2012); C. Berka zougali et al. (2012); D. Bouzabata et al. (2013); E. Foudil-Cherif et al. (2013); F. Ben Ghnaya et al. (2013); G. Hennia et al. (2015); H. Benchikh et al. (2016); I. Touaibia (2016); J. Barhouchi et al. (2016); K. Bekhechi et al. (2019) 


\section{Essential oil analysis}

The essential oils were analyzed using a HewlettPackard gas chromatograph (CG/FID 7890), coupled to a gas chromatograph (CG/MS 7890/5975C), equipped with a Column Apolar: DB5 MS: $40 \mathrm{~m} 0.18 \mathrm{~mm} 0.18 \mu \mathrm{m}$ and programming from $50^{\circ} \mathrm{C}$ for $5 \mathrm{~min}$ at a rate of $5^{\circ} \mathrm{C} / \mathrm{min}$ up to $300^{\circ} \mathrm{C}$. Helium was used as the carrier gas $(1.0 \mathrm{ml} / \mathrm{min})$; injection in the split mode (1:30). The injector and detector temperature was $280^{\circ} \mathrm{C}$ with the split mode of $1 / 100$. The mass spectrometer worked in the EI mode at $70 \mathrm{eV}$; electron multiplier, $2500 \mathrm{~V}$; ion source temperature, $180^{\circ} \mathrm{C}$. The MS data were acquired in the scan mode in the $\mathrm{m} / \mathrm{z}$ range of 33-450. The identification of the components was based on comparing their mass spectra with those of NIST mass spectral library (Masada 1976; NIST 2002) and those described by Adams. The comparison of their retention indices either with those of authentic compounds or with literature values (Adams 2007).

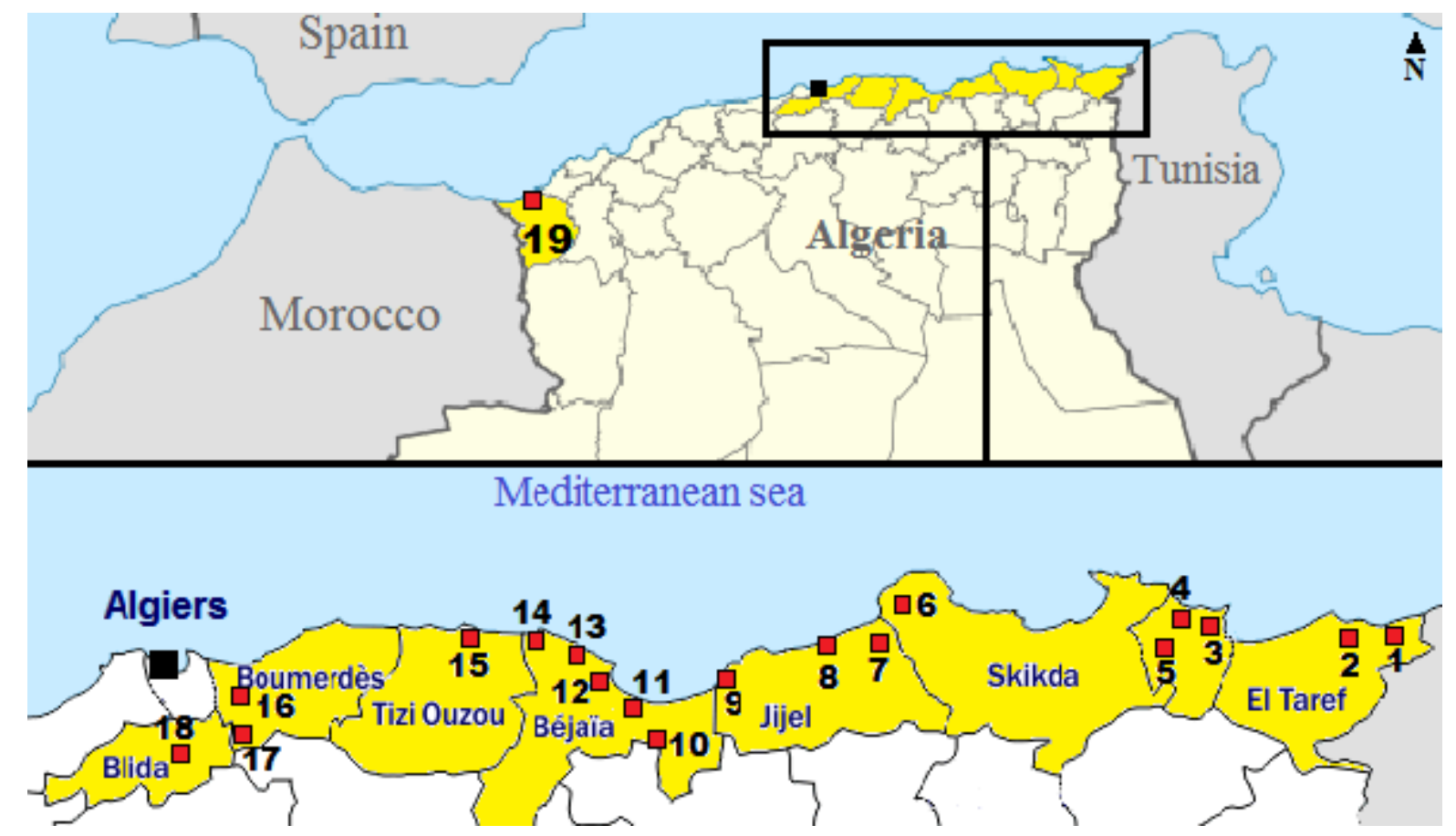

Figure 1. The sampling sites of Myrtus communis (for the numbers, see Table 2)

Table 2. Geographical coordinates of Myrtus communis sampling sites

\begin{tabular}{|c|c|c|c|c|c|}
\hline \multirow{2}{*}{ Province } & \multirow{2}{*}{\multicolumn{2}{|c|}{ Localities }} & \multicolumn{2}{|c|}{ GPS Coordinates } & \multirow{2}{*}{ Elevation (m) } \\
\hline & & & North & East & \\
\hline \multirow[t]{2}{*}{ El-Tarf } & 1 & El-Kala & $36^{\circ} 51^{\prime} 54.74^{\prime \prime}$ & $8^{\circ} 26^{\prime} 38.16^{\prime \prime}$ & 54 \\
\hline & 2 & Berrihane & $36^{\circ} 50^{\prime} 32.46^{\prime \prime}$ & $8^{\circ} 08^{\prime} 37.45^{\prime \prime}$ & 9 \\
\hline \multirow[t]{3}{*}{ Annaba } & 3 & Annaba & $36^{\circ} 55^{\prime} 43.18^{\prime \prime}$ & $7^{\circ} 42^{\prime} 54.75^{\prime \prime}$ & 500 \\
\hline & 4 & Séraïdi & $36^{\circ} 54^{\prime} 56.17^{\prime \prime}$ & 7³7'14.93" & 650 \\
\hline & 5 & Oued ElAneb & $36^{\circ} 54^{\prime} 35.38^{\prime \prime}$ & 7³3'16.46" & 95 \\
\hline Skikda & 6 & Laouinet & $36^{\circ} 58^{\prime} 55.38^{\prime \prime}$ & $6^{\circ} 18 ' 20.06 "$ & 650 \\
\hline \multirow[t]{3}{*}{ Jijel } & 7 & Elkhemis & $36^{\circ} 48^{\prime} 04.66^{\prime \prime}$ & $6^{\circ} 17^{\prime} 10.62^{\prime \prime}$ & 44 \\
\hline & 8 & Timdiouan & $36^{\circ} 50^{\prime} 40.58^{\prime \prime}$ & $6^{\circ} 01^{\prime} 41.65^{\prime \prime}$ & 35 \\
\hline & 9 & Taza & $36^{\circ} 41^{\prime} 54.58^{\prime \prime}$ & $5^{\circ} 31^{\prime} 53.29^{\prime \prime}$ & 42 \\
\hline \multirow[t]{5}{*}{ Bejaïa } & 10 & Darguina & $36^{\circ} 34^{\prime} 45.07^{\prime \prime}$ & $5^{\circ} 20^{\prime} 30.72^{\prime \prime}$ & 100 \\
\hline & 11 & Azemour & $36^{\circ} 38^{\prime} 39.53^{\prime \prime}$ & $5^{\circ} 12^{\prime} 49.73^{\prime \prime}$ & 22 \\
\hline & 12 & Ibourassen & $36^{\circ} 42^{\prime} 43.77^{\prime \prime}$ & $5^{\circ} 00^{\prime} 09.91^{\prime \prime}$ & 27 \\
\hline & 13 & Boulimat & $36^{\circ} 48^{\prime} 36.07^{\prime \prime}$ & $4^{\circ} 59^{\prime} 18.79^{\prime \prime}$ & 60 \\
\hline & 14 & Beni Ksila & $36^{\circ} 53^{\prime} 09.78^{\prime \prime}$ & $4^{\circ} 38^{\prime} 58.35^{\prime \prime}$ & 30 \\
\hline Tizi-ouzou & 15 & Isoumaten & $36^{\circ} 52^{\prime} 43.37^{\prime \prime}$ & $4^{\circ} 20^{\prime} 40.60^{\prime \prime}$ & 123 \\
\hline \multirow[t]{2}{*}{ Boumerdes } & 16 & Zemmouri & $36^{\circ} 45^{\prime} 43.20^{\prime \prime}$ & $3^{\circ} 34^{\prime} 42.41^{\prime \prime}$ & 233 \\
\hline & 17 & Talaougouni & $36^{\circ} 35^{\prime} 27.26^{\prime \prime}$ & $3^{\circ} 29^{\prime} 31.38^{\prime \prime}$ & 400 \\
\hline Blida & 18 & Hamam Melouan & $36^{\circ} 29^{\prime} 18.32^{\prime \prime}$ & $3^{\circ} 03^{\prime} 02.90^{\prime \prime}$ & 169 \\
\hline Tlemcen & 19 & Honaïn & $35^{\circ} 08^{\prime} 10.27^{\prime \prime}$ & $1^{\circ} 40 ' 34.34 "$ & 647 \\
\hline
\end{tabular}




\section{Antimicrobial activity}

The antimicrobial activities of the essential oil were evaluated against four Gram-positive bacteria and six Gram-negative bacteria. Gram-positive bacteria used in this study were Staphylococcus aureus ATCC 25293, S. aureus MRSA ATCC 433000, Bacillus cereus ATCC 10876, and Enterococcus faecalis ATCC 49452. Gram-negative bacteria used in this study were Klebsiella pneumonia ATCC 700603, Escherichia coli ATCC 25922, Proteus mirabilis ATCC 35659, Serratia marcescens, S. liquefaciens, and Salmonella enterica. Bacterial inoculums were prepared from overnight broth culture in physiological saline $(0.8 \%$ of $\mathrm{NaCl}$ ) to obtain an optical density ranging from 0.08 to 0.1 at $625 \mathrm{~nm}$. Muller Hinton agar (MHA) was placed in Petri dishes, solidified, and inoculated with the test bacteria. Sterile discs $(6 \mathrm{~mm})$ filled with $10 \mu \mathrm{l}$ of undiluted and diluted essential oil (1/1,1/2,1/3 v/v of DMSO) were placed on inoculated agar. DMSO was used as a negative

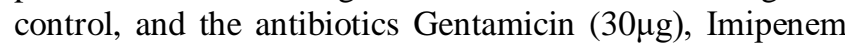
$(10 \mu \mathrm{g})$, Cefotaxime $(30 \mu \mathrm{g})$, and Colistin $(10 \mu \mathrm{g})$ were used as the positive control. The bacterial growth inhibition was determined as the diameter of the inhibition zones around the discs. All the tests were performed in triplicate, and the means were calculated as results. The Petri dishes were incubated at $37^{\circ} \mathrm{C}$ for 18 to $24 \mathrm{~h}$ aerobically. After incubation, inhibition zone diameters were measured and documented (Dahiya and Purkayastha, 2012). The sensitivity to the essential oil was classified according to the diameter of the inhibition halos as follows: not sensitive (-) for diameters less than $8 \mathrm{~mm}$; sensitive (+) for diameters ranging from 9 to $14 \mathrm{~mm}$; very sensitive (++) for diameters ranging from $15-19 \mathrm{~mm}$ and extremely sensitive (+++) for diameters larger than $20 \mathrm{~mm}$ (Ponce et al. 2003).

\section{Statistical analysis}

Firstly, the data were subjected to the Principal Components Analysis (PCA) to examine the relationships among the terpenes compounds and identify the possible structure of the populations. Cluster analysis (UPGMA) was carried out on the original variables and on the Manhattan distance matrix to determine hierarchical associations among the populations. The cluster analyses were carried out using Statistica v10 software. The antibacterial activity results were analyzed by the ANOVA three-way Completely Randomized (populations, doses, and bacteria) is performed by using the CoStat statistical software package. All analyses were performed at the 5\% significance level $(\mathrm{P}<0.05)$.

\section{RESULTS AND DISCUSSION}

The hydrodistillation of $M$. communis produces a pale yellow essential oil with a pleasant odor. The populations studied have an average yield of $0.68 \pm 0.6 \%$. The highest yield $(2.52 \%)$ is observed in Ibourassen population oil, the lowest yield $(0.1 \%)$ is obtained from the population oil of Boulimat. It is noted that the yield of essential oil of $M$. communis is directly related to the altitude. The highest yield was found from the lowland populations, while the low yield was found from the highland populations. The regression curve confirms the yield reduction; most of the populations studied have an average yield (Figure 2).

The chemical composition analysis of essential oils from the 19 populations of M. communis by CG / MS allowed the identification of 46 chemical components representing an average of $99.17 \pm 0.6 \%$ of the total oil (Table 3). The $\alpha$-pinene was the most abundant component in the essential oils of all populations, with a mean of 50.1 $\pm 10.3 \%$. It was followed by the 1,8 -cineole $(22.27 \pm$ $4.32 \%)$. These two components account for $70 \%$ of the total oil. We also note the presence of limonene (5.16 \pm $2.67 \%)$, linalool $(3.79 \pm 2.97 \%)$, $\alpha$-terpineol $(2.75 \pm$ $1.12 \%)$, geranyl acetate $(1.95 \pm 0.7 \%)$ and methyl eugenol $(1.40 \pm 0.98 \%)$. However, myrtenyl acetate is only observed in four populations with significant contents (10.66-20.94\%).

The results showed that $M$. communis essential oils from different populations show variability in the chemical composition. The relationship between populations was estimated by a principal component analysis (PCA). The composition of $M$. communis essential oils shows significant differences. The major compounds show a few variability inter-populations (Figure 3).

The first clade includes four populations (Boulimat, Darguina, Azemour, and Taza); characterized by myrtenyl acetate at relatively high levels (10.66-20.94\%). Other populations do not contain myrtenyl acetate. Azemour and Taza populations are similar in their high levels of linalool $(9.83-12.83 \%)$. On the other hand, Boulimat and Darguina populations have low myrtenyl acetate (10.66-13.80 \%) and limonene (2.24-10.09\%). The Three-dimensional spatial projection shows that Boulimat and Darguina populations are nevertheless very different (Figure 4).

The second clade includes 15 populations of $M$. communis characterized by the presence of high levels of $\alpha$-pinene. The Honain population was separated from the group due to a relatively high neryl formate $(3.74 \%)$ and cis-pinocarvyl acetate $(2.78 \%)$. The remaining populations are characterized by the presence of geranyl acetate. Oued El-Aneb population in this clade has the highest content of $\alpha$-pinene $(64.3 \%)$, the lowest content of 1,8-cineole $(10.25 \%)$, and the presence of $\alpha$-terpinyl acetate $(1.55 \%)$. The Berrihane, Timdiouan, Melouan, Laouinet, Ibourassen, Isoumaten, and Beni Ksila populations have a significant level of 1,8-cineole (21.39-28.44\%). The populations of ElKala, Zemmouri, Annaba, Talaougouni, Séraidi, and Elkhemis form a group characterized by high levels of $\alpha$ pinene (55.92-61.81\%), 1,8-cineole (17.41-20.61\%) and relatively low limonene $(2.52-5.79 \%)$. Based on the chemical composition and the UPGMA analyzes, the $M$. communis in this study were grouped into six chemotypes (Table 4).

The antibacterial activity of $M$. communis oils was determined by the disk diffusion method. The result was presented in Table 5.

The essential oil from Berrihane population had the weakest antibacterial activity against all bacteria tested with an inhibitory diameter ranging from 8 to $14 \mathrm{~mm}$. The essential oil from the population of Laouinet was very 
effective against $S$. aureus $R M$ with an inhibitory diameter of $40 \mathrm{~mm}$. It was ineffective against $S$. marcescens and $E$. coli. strain has low sensitivity to the essential oils of $M$. communis. The best activities of essential oils against $E$. coli are those of Boulimat and Isoumaten populations.

The analysis of variance made it possible to highlight the interactions between essential oils, dilutions, and bacteria; their actions and interactions are highly significant $(\mathrm{P}<0.001)$ (Table 6).

The ANOVA shows that the essential oil of the population of Talaougouni has the best activity against the bacteria tested with an average zone of inhibition $(13.57 \mathrm{~mm})$. The essential oil of the population of Berrihane has the lowest antibacterial activity, with an average inhibition of $11.42 \mathrm{~mm}$ (Table 7).
The bacteria tested are susceptible to gentamicin. The non-diluted essential oil has the same antibacterial activity as Imipeneme, while two-fold and three times dilutions of the oils have no antibacterial activity (Table 8).

$S$. aureus strain was the most sensitive, with an average inhibition diameter of $17.85 \mathrm{~mm}$, while S. liquefaciens is the least sensitive strain to essential oils of M. communis (Table 9).

Desirability profile showed a value of 0.823 ; therefore, the essential oils of $M$. communis could be categorized as highly desirable. It confirms the ANOVA statistical analysis results for all interactions between essential oils, dilutions, and bacteria (Figure 6).

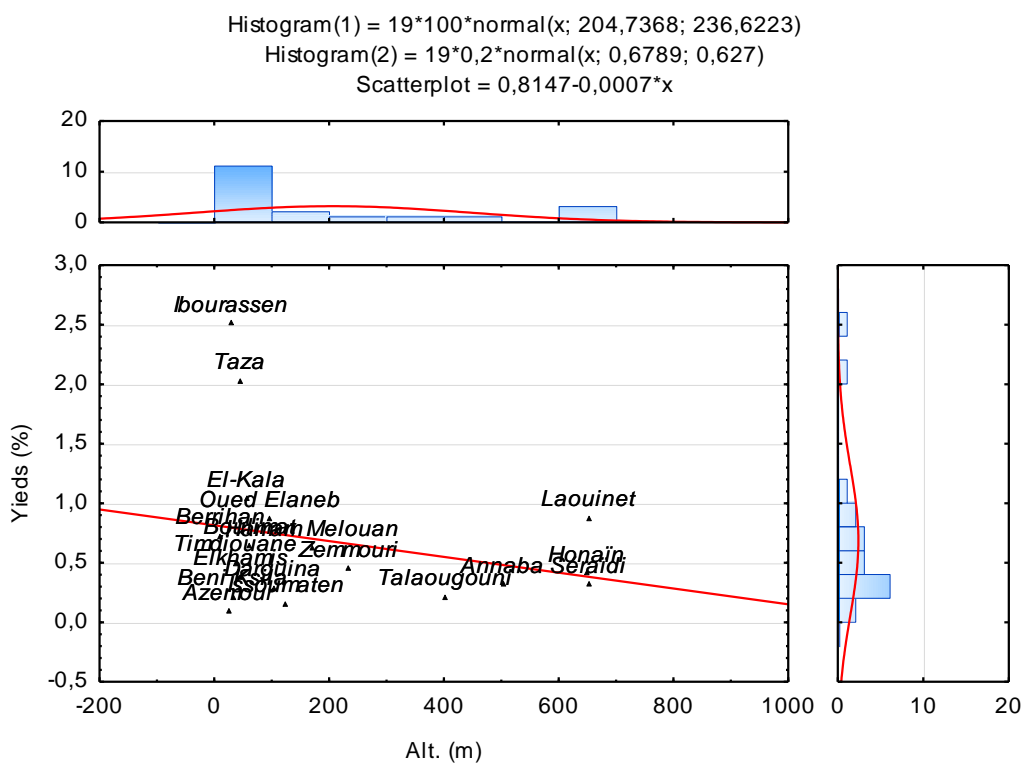

Figure 2. Essential oil yields of the Myrtus communis populations

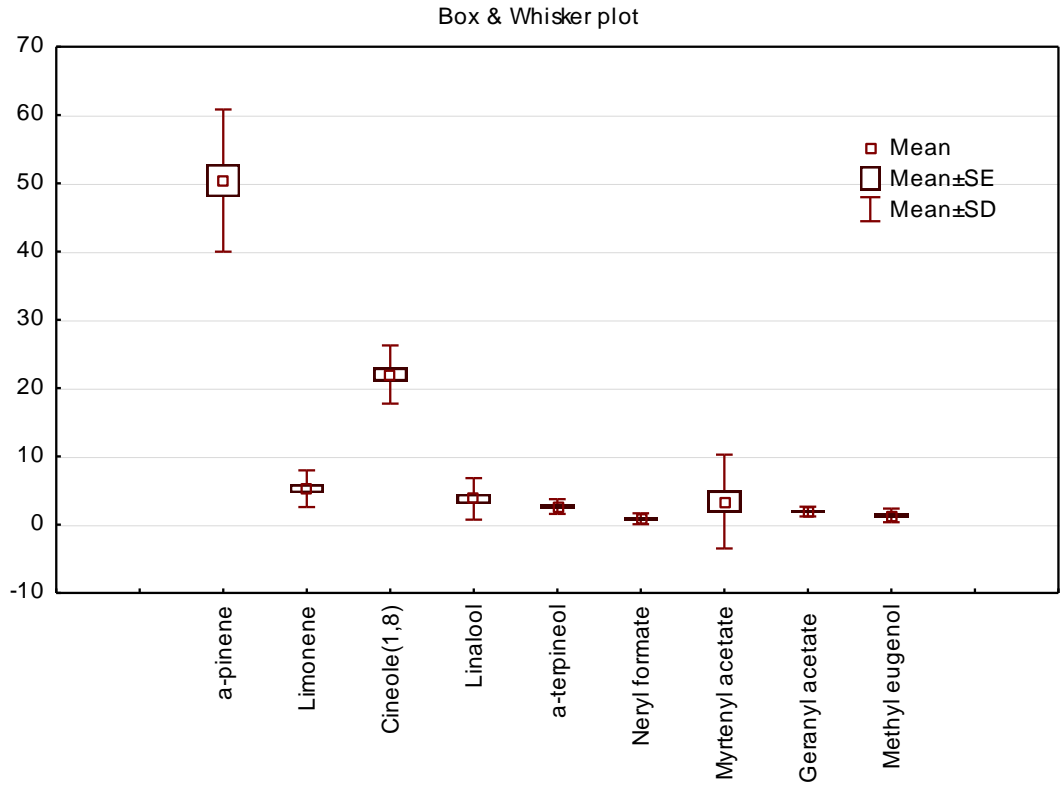

Figure 3. Variability of major components of Myrtus communis essential oils 


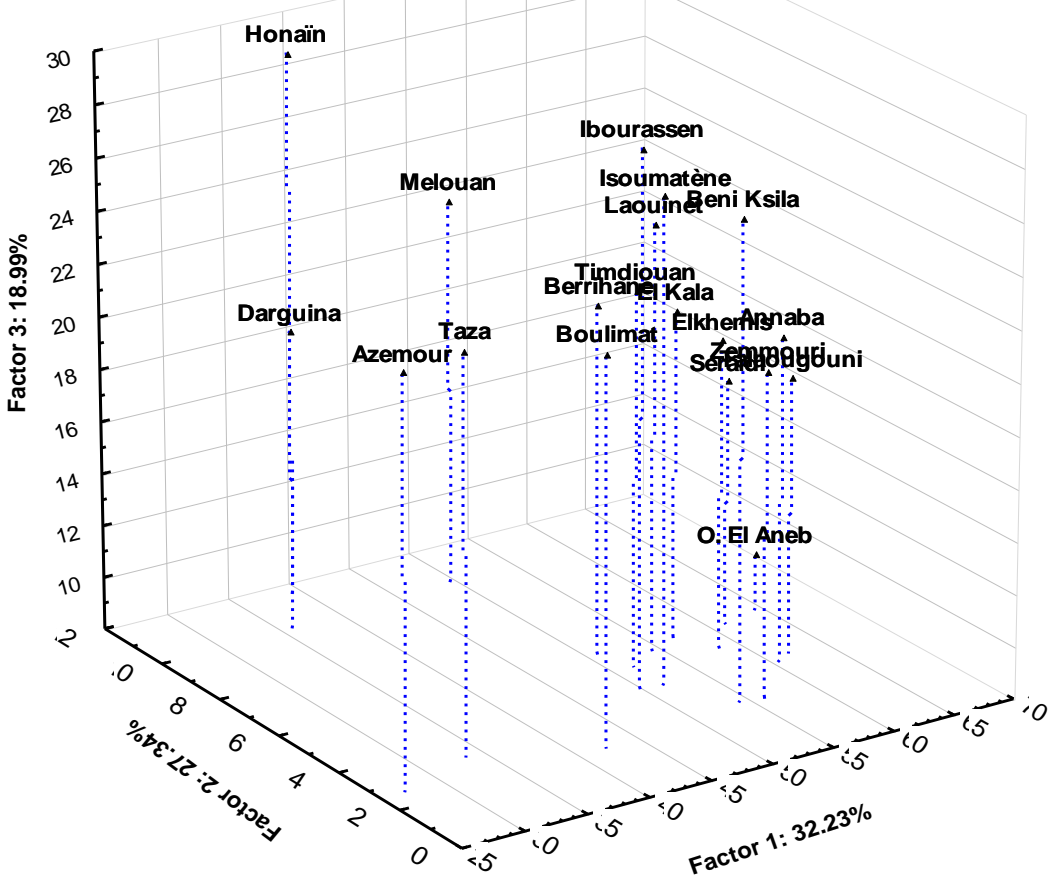

Figure 4. Three-dimensional spatial projection of Myrtus communis populations

Unweig hted pair-group average, City-block (Manhattan) distances

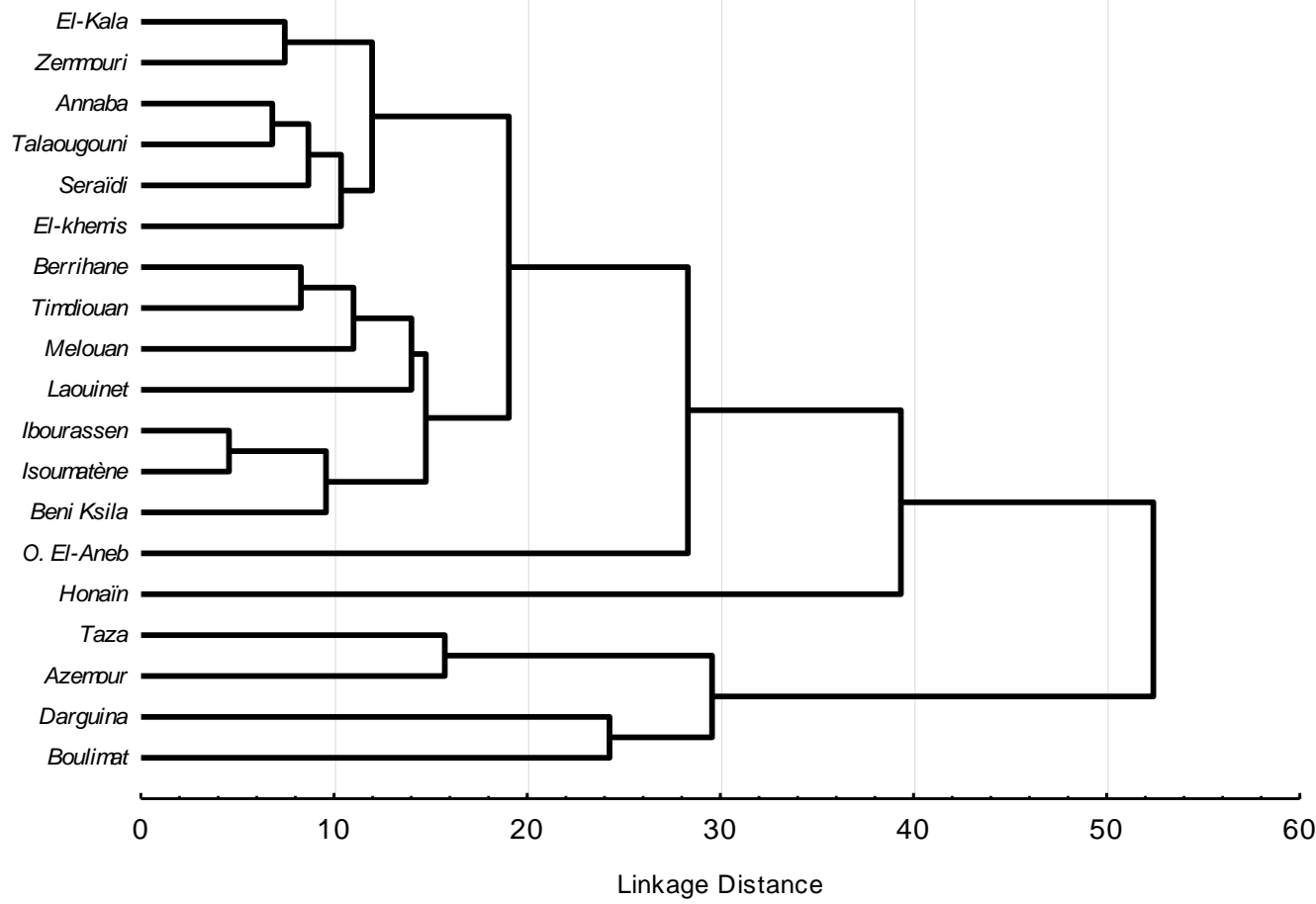

Figure 5. The result of the UPGMA of Myrtus communis populations 
Table 3. Chemical composition of Myrtus communis essential oils

\begin{tabular}{|c|c|c|c|c|c|c|c|c|c|c|c|c|c|c|c|c|c|c|c|c|c|c|}
\hline Localities & & $\begin{array}{l}\frac{\pi}{\sqrt{\pi}} \\
\text { I }\end{array}$ & 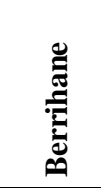 & 递 & 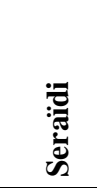 & $\begin{array}{l}\overline{0} \\
\dot{\Xi} \\
\text { 조 } \\
\dot{0}\end{array}$ & 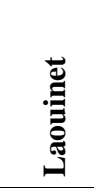 & 绨 & 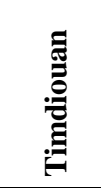 & $\underset{\mathbb{W}}{\mathbb{N}}$ & 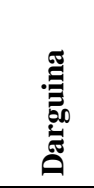 & 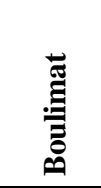 & 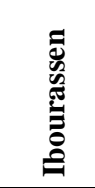 & 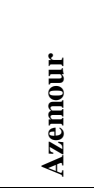 & 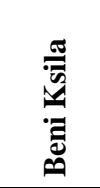 & 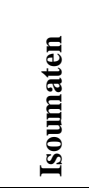 & $\begin{array}{l}\stackrel{\Xi}{\Xi} \\
\stackrel{\Xi}{\Xi} \\
\text { N }\end{array}$ & 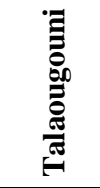 & 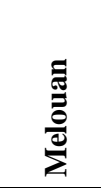 & 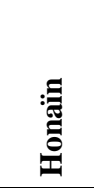 & 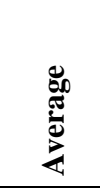 & की \\
\hline Yield \% & & 1.05 & 0.74 & 0.33 & 0.33 & 0.88 & 0.89 & 0.4 & 0.51 & 2.04 & 0.3 & 0.1 & 2.52 & 0.66 & 0.23 & 0.17 & 0.46 & 0.23 & 0.64 & 0.42 & 0.68 & 0.6 \\
\hline Number of compounds & KI & 32 & 26 & 29 & & 30 & 27 & & 29 & 27 & & & 32 & & & 27 & & & & & & \\
\hline Total oils\% & & 99.44 & 99.08 & 99.17 & 9.75 & 98.67 & 97.96 & 9.31 & 99.40 & 99.65 & 8.23 & 99.85 & 99.39 & 98.84 & 99.75 & 98.40 & 98.78 & 99.84 & 99.95 & 98.86 & 99.17 & 0.6 \\
\hline Hexen & 852 & 0.32 & 0.58 & 0.25 & 0.14 & 0.07 & & & 0.52 & & & & & & & & 0.19 & 0.15 & 0.39 & 0.12 & 0.28 & 0.26 \\
\hline butanoate & & & 0.54 & 0.15 & 0.24 & 0.19 & & & 0.44 & & & & & 29 & & & 18 & 8 & & 00 & & 0.12 \\
\hline & & & & 0.28 & & 0.52 & & & 0.40 & & & & & & & & & & & 47 & & 0.10 \\
\hline & & & & & & & & & 51.6 & & & & & & & & & & & & & 10.3 \\
\hline & & & & & & & & & 0.0 & & & & & 0 & c & & 00 & 0 & & 00 & & .03 \\
\hline$\beta-\mathrm{p}$ & & & .37 & & & 0.38 & 0 & & 0.39 & & 0.2 & 0.3 & 0.47 & 0.28 & 8 & 0.49 & 0.56 & .56 & 0.51 & 0.05 & 10 & 0.13 \\
\hline & & & 0.70 & .08 & & 0.11 & 0.10 & 11 & 0.00 & 0.00 & 0.00 & 0.00 & 0.00 & 0.00 & 0.00 & 0.00 & 0.00 & 0.00 & 0.00 & 0.12 & 0.08 & 0.16 \\
\hline & & & & & & 0.42 & & & 0.17 & & & & & & & & 0.00 & .11 & & & 3 & 0.12 \\
\hline & & & 0.59 & & & 0.77 & 0.20 & & 0.59 & & & 0.2 & 0.24 & & 0.3 & 0.40 & 0.3 & 0.3 & & 57 & 0. & 0.18 \\
\hline & & & 0.25 & 0.1 & & 0.16 & 0.00 & & 0.17 & 0.00 & 9 & & 0.08 & 0.00 & 0.1 & 0.15 & 0. & 0.1 & 0.0 & 0.24 & 0. & 0.07 \\
\hline Cyn & 26 & 41 & 1.06 & 0.47 & 0.88 & 1.15 & 0.46 & 0.91 & 0.61 & 0.65 & 0.49 & 0.55 & 0.55 & 0.38 & 0.78 & 0.76 & 0.77 & 1.01 & 0.63 & 1.13 & 0.71 & 0.25 \\
\hline & & & 5.92 & 3.79 & & 6.05 & 5.49 & & 5.05 & & & & 4.14 & & & 4.06 & 2.52 & 1 & & 11.48 & 5.1 & 2.67 \\
\hline & & 0.61 & 21.39 & 20.51 & 7.41 & 10.25 & 24.34 & 19.84 & 22.38 & 23.29 & 19.45 & 2.87 & 28.44 & 23.65 & 26.32 & 26.52 & 20.51 & 18.60 & 22.81 & 8.79 & 22.27 & 4.32 \\
\hline & & & 00 & 0.44 & 0.30 & 44 & 0.24 & 0.49 & 0.00 & 0.0 & 5 & & 0.00 & & 0 & 0.00 & 0.00 & 0 & .00 & 0.26 & 7 & .26 \\
\hline & & & & & & 0.82 & 0.2 & & 0.8 & & & & & 0.22 & 0. & 52 & 42 & 5 & & 0.90 & 5 & 0.20 \\
\hline & & & 0.77 & & & 1.07 & 0.37 & & 0.94 & 0.2 & & 0.4 & 0.41 & 0.33 & 0.4 & 0.63 & 0.52 & 0.58 & 0.31 & 1.11 & .56 & 0.25 \\
\hline & & & & & & & & & & & & & & & 0.0 & & 0 & 0 & 0.0 & 0.10 & 3 & 0.04 \\
\hline & & & & & & & & & & & & & & & & & & & & 1.50 & & 2.97 \\
\hline Met & & & & & & 0.00 & 2.75 & & 0.00 & 0.0 & & 0.0 & 0.26 & 0.00 & 0.0 & 0.00 & 0.00 & 0.00 & 0.23 & 0.15 & 0.23 & 0.61 \\
\hline & 145 & & 0.00 & & & 0.21 & 0.22 & & 0.00 & 0.00 & & 0.2 & 0.00 & 0.00 & 0.2 & 0.00 & 0.00 & 0.14 & 0.20 & 0.05 & .10 & 0.11 \\
\hline Terp & 185 & 0.21 & 0.30 & 0.24 & 0.28 & 0.29 & 0.26 & & 0.32 & 0.29 & 0.26 & 0.0 & 0.27 & 0.23 & 0.1 & 0.35 & 0.29 & 0.27 & 0.26 & 0.46 & .33 & 0.34 \\
\hline & & & 2.94 & & & & & & & & & & & & & 3.84 & & 2.50 & & 3.37 & & 1.12 \\
\hline & & & & & & & & & & & & & & & & & 0.00 & 0.00 & & 0.00 & 0.10 & 0.31 \\
\hline & & & & & & & & & & & & 0.0 & 0.00 & 0.0 & 0.0 & 0.00 & 0.00 & 0.00 & 0.0 & 0.00 & 0.01 & .04 \\
\hline & & & & & & & & & & & & & & & & & 0.00 & .00 & & 0.53 & 0.21 & .27 \\
\hline & & & & & & & & & & & & & & 0.7 & & & 0.39 & 3 & 0.44 & 3.74 & 0.88 & 0.77 \\
\hline & & & & & & & & & & & & & & & & & & & & 2.78 & 0.17 & 0.62 \\
\hline & & 0.00 & 0.00 & 0.00 & 0.00 & 0.00 & 0.00 & 0.00 & 0.00 & 18.05 & 13.80 & 10.66 & 0.14 & 20.94 & 0.00 & 0.17 & 0.10 & 0.15 & 0.00 & 0.46 & 3.48 & 6.70 \\
\hline$\alpha$-terpinyl acetate & 1350 & 0.11 & 0.84 & 0.00 & 0.54 & 1.55 & 0.80 & 0.36 & 0.00 & 0.15 & 0.29 & 0.22 & 0.00 & 0.22 & 0.00 & 0.00 & 0.51 & 0.00 & 0.56 & 0.08 & 0.32 & 0.39 \\
\hline
\end{tabular}




\begin{tabular}{|c|c|c|c|c|c|c|c|c|c|c|c|c|c|c|c|c|c|c|c|c|c|c|}
\hline Eugenol & 356 & 0.47 & 0.00 & 0.00 & .10 & 0.64 & 0.33 & 0.51 & 0.00 & 0.00 & 0.00 & 0.30 & 0.14 & 0.00 & 0.20 & 0.00 & 0.21 & 0.00 & 0.25 & 0.19 & 0.17 & 0.20 \\
\hline Geranyl acetate & 78 & 2.98 & 3.28 & 1.22 & 2.13 & 1.42 & 1.67 & 1.55 & 1.66 & 1.71 & & 2.07 & 1.90 & 1.98 & 2.13 & 1.99 & 2.54 & 1.88 & 2.85 & 0 & 1.95 & 0.70 \\
\hline$\beta$-elemene & 395 & 0.00 & 0.00 & 0.00 & 0.00 & 0.00 & 0.00 & 0.00 & 0.00 & 0.00 & 0.14 & 0.22 & 0.23 & 0.18 & 0.23 & 0.12 & 0.25 & 0.12 & 0.00 & .12 & 0.10 & 0.11 \\
\hline Methyl eugenol & 401 & 1.48 & 1.42 & 0.72 & 0.54 & 0.00 & 0.22 & 0.29 & 0.92 & 1.65 & 1.23 & 2.53 & 2.20 & 1.05 & 1.77 & 2.47 & 3.97 & 2.04 & 1.19 & .23 & 1.40 & 0.98 \\
\hline & 430 & 0.88 & 0.48 & 1.19 & 1.63 & 0.00 & 0.29 & 0.38 & 0.97 & 0.35 & 0.44 & 0.48 & 0.32 & 0.34 & 0.40 & 0.54 & 0.77 & 0.40 & 1.26 & 0.00 & .58 & 0.42 \\
\hline & 35 & 0.07 & 0.00 & 0.13 & 0.28 & 0.00 & 0.00 & 0.33 & 0.19 & 0.00 & 0.00 & 0.00 & 0.00 & 0.00 & 0.07 & 0.22 & 0.10 & 0.19 & 0.15 & .00 & .09 & 0.11 \\
\hline & 66 & 0.33 & 0.69 & 0.24 & 0.48 & 0.25 & 0.00 & 0.37 & 0.48 & 0.24 & 0.46 & 0.75 & 0.25 & 0.61 & 0.21 & 0.24 & .40 & 0.23 & 0.23 & .07 & 34 & 0.19 \\
\hline & 99 & 0.00 & 0.00 & 0.00 & 0.00 & 0.00 & & 0.00 & & & 0.00 & & & & & 0.20 & & & & & & 0.17 \\
\hline & 06 & 00 & & 00 & 0 & 0.0 & & U & & 0.2 & & & 0. & & & 0. & & & & & & 0.18 \\
\hline & 25 & 00 & 0.00 & 0.00 & 00 & 0.00 & 0.00 & 0.00 & 0.09 & 0.00 & 0.0 & 0.00 & 0.11 & & 0.17 & 0.00 & & 0.12 & 00 & & 03 & 0.06 \\
\hline$\gamma$-bi & 32 & 0.00 & 0.00 & 0.00 & 0.00 & 0.00 & 0.00 & 0.00 & 0.18 & 0.00 & 0.1 & 0.00 & 0.14 & 0.00 & 0.00 & 0.00 & 0 & 0.00 & 0.00 & & 0.02 & 0.06 \\
\hline Flav & 41 & 0.00 & 0.00 & 0.00 & 0.00 & 0.00 & 0.00 & 0.00 & 0.13 & 0.00 & 0.00 & 0.00 & 0.00 & 0.00 & 0.00 & 0.00 & 0.00 & 0.00 & 0.09 & 0 & 0.01 & 0.03 \\
\hline Ger & 71 & 0.06 & 0.00 & 0.13 & 0.27 & 0.13 & 0.20 & 0.27 & 0.19 & 0.00 & 0.00 & 0.00 & 0.00 & 0.00 & 0.00 & 0.00 & 0.00 & 0.18 & 0.13 & 0 & 0.08 & 0.10 \\
\hline Spat & 88 & 0.00 & 0.00 & .00 & 0.00 & 0.00 & 0.00 & 0.35 & 0.00 & 0.00 & 0.00 & 0.12 & 0.00 & 0.00 & 0.00 & 0.00 & 0.17 & 0.00 & 0.10 & & 0.04 & 0.09 \\
\hline Cary & 1595 & 0.51 & 0.56 & 0.24 & 0.25 & 0.38 & 0.28 & 0.18 & 0.28 & 0.20 & 0.00 & 0.21 & 0.24 & 0.00 & 0.00 & 0.00 & 0.42 & 0.00 & 0.79 & 0 & 0.24 & 0.22 \\
\hline Hum & 1627 & 0.00 & 0.13 & 0.00 & 0.00 & 0.00 & 0.00 & 0.00 & 0.00 & 0.00 & 0.00 & 0.00 & 0.00 & 0.39 & 0.00 & 0.00 & 0.13 & 0.00 & 0.00 & 0.0 & 0.03 & 0.09 \\
\hline Intermedeol-neo & 1671 & 0.00 & 0.00 & 0.00 & 0.00 & 0.00 & 0.00 & 0.20 & 0.00 & 0.07 & 0.00 & 0.08 & 0.18 & 0.00 & 0.00 & 0.00 & 0.03 & 0.00 & 0.06 & 0.04 & 0.04 & 0.07 \\
\hline
\end{tabular}




\section{Discussion}

The average yield of $M$. communis essential oil was $0.68 \pm 0.6 \%$. This result is similar to the yield obtained in previous studies on Algerian M. communis. The average yield of samples from Baïnem (Algiers) was $0.51 \pm 0.04 \%$ (Berka-Zougali et al. 2010). Tenes samples had an average yield ranging from 0.28 to $0.77 \%$ (Hennia et al. 2015). Barhouchi et al. (2016) obtained a high yield of $1.14 \%$ of Annaba populations, and the average yield of samples from Honaïn was 0.52\% (Belmimoun et al. 2016).

Studies of myrtle from other countries showed the same yields. In Tunisia, Aidi et al. (2010) obtained an average of $0.61 \%$, but a study by Gardeli et al. (2008) had an average yield of 1.2 to $1.45 \%$. The yield of Iranian myrtle ranging from 0.8 to $2.2 \%$ (Salimi et al. 2017). The difference in yield might be affected by exposure to the sun. Generally, essential oil production is higher in high sun exposure
(Schuh et al. 1997; Fadil et al. 2016).

The chemical composition analysis of essential oils from the 19 populations of $M$. communis showed that $\alpha$ pinene is the most abundant component in the essential oils of all populations studied. It was followed by the 1,8 cineole. Several studies have reported similar results. The $\alpha$-pinene in oils from Annaba and Jijel populations was higher than 50\% (Bouzabata et al. 2010; Barhouchi et al. 2016, Benchikh et al. 2016). The essential oil of $M$. communis from Tunisia oil contains $58.1 \%$ of $\alpha$-pinene (Aidi et al. 2010), and Corsican myrtle oils also have high levels of $\alpha$-pinene (Bradesi et al. 1997). Two other monoterpenes, 1,8-cineole, and myrtenyl acetate are found at predominant levels. These monoterpenes are found in oils from Morocco (Cherrat et al. 2014; Fadil et al. 2017) and Cyprus (Akin et al. 2010).

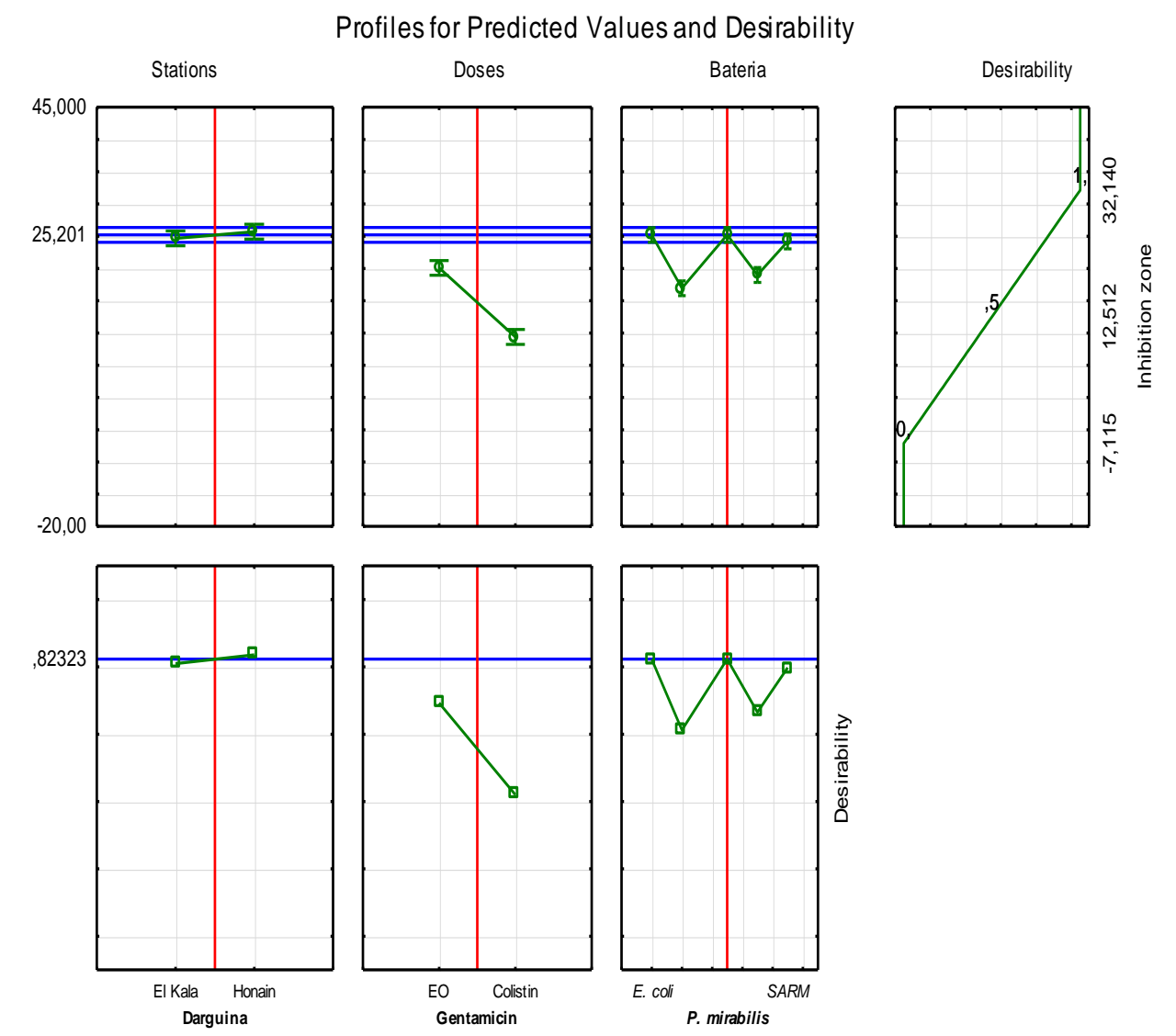

Figure 6. Profile of Predicted Values and Desirability of Myrtus communis essential oils

Table 4. Chemotype of Myrtus communis in Algeria

\begin{tabular}{llll}
\hline Chemotypes & & Populations \\
\hline$\alpha$-pinène & 1,8-cineole & Limonene & $\begin{array}{l}\text { El-Kala, Zemmouri, Annaba, Telaougouni, Seraïdi, EL-Khemis, Berrihane, } \\
\text { Timdiouan, Melouan, Laouinet, Ibourassen, Isoumaten, Beni Ksila }\end{array}$ \\
& & $\begin{array}{l}\text { A-terpenyl acetate } \\
\text { Oued El-Aneb }\end{array}$ & $\begin{array}{l}\text { Honaïn } \\
\text { Limonene }\end{array}$ \\
& Neryl formate & Azemour, Taza \\
Myrtenyl & Linalool & A-pinene & Boulimat \\
acetate & A-pinene & Darguina & \\
& & Limonene & \\
\hline
\end{tabular}


Table 5. The diameter of growth inhibition of Myrtus communis essential oils against ten isolates of bacteria

\begin{tabular}{|c|c|c|c|c|c|c|c|c|c|c|c|}
\hline \multirow[b]{2}{*}{ Populations } & \multicolumn{11}{|c|}{ Inhibition zone (mm) } \\
\hline & 兽 & $\begin{array}{l}\tilde{\Xi} \\
\dot{8} \\
\dot{0}\end{array}$ & 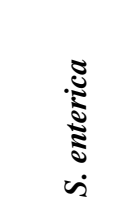 & 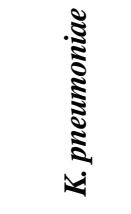 & 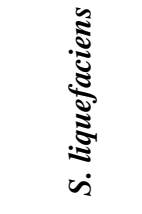 & 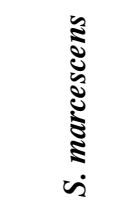 & 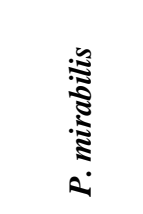 & 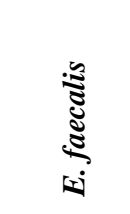 & 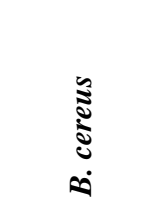 & 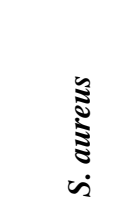 & 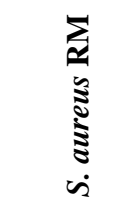 \\
\hline \multirow[t]{3}{*}{ El Kala } & 1 & $9.3 \pm 1.2$ & $21 \pm 3.6$ & $16 \pm 5.3$ & $11 \pm 1$ & $12 \pm 1$ & $8 \pm 0$ & $17.7 \pm 0.6$ & $19 \pm 1.7$ & $13.3 \pm 3.1$ & $20 \pm 0$ \\
\hline & $1 / 2$ & 0 & $8.7 \pm 0.6$ & $8 \pm 0$ & 0 & $7 \pm 0$ & $7.3 \pm 1.5$ & $8.7 \pm 0.6$ & $8.7 \pm 2.3$ & 11.71 .5 & $7 \pm 1$ \\
\hline & $1 / 3$ & 0 & $7.3 \pm 0.6$ & 0 & 0 & 0 & 0 & $7 \pm 0$ & 0 & $8.3 \pm 2.1$ & 0 \\
\hline \multirow[t]{3}{*}{ Berrihane } & 1 & $8.7 \pm 0.6$ & $14 \pm 1$ & $10.3 \pm 0.6$ & $9 \pm 0$ & $9.5 \pm 0.5$ & $9 \pm 0$ & $10.7 \pm 0.6$ & $12.3 \pm 0.6$ & $14 \pm 1$ & $12 \pm 1$ \\
\hline & $1 / 2$ & $7 \pm 1$ & $8.7 \pm 0.6$ & $7 \pm 0$ & 0 & $7 \pm 1$ & $8.7 \pm 0.6$ & $7 \pm 0$ & $9.3 \pm 0.6$ & $7.3 \pm 1.2$ & $7.7 \pm 0.6$ \\
\hline & $1 / 3$ & 0 & $7 \pm 1$ & 0 & 0 & 0 & 0 & 0 & 0 & 0 & 0 \\
\hline \multirow[t]{3}{*}{ Annaba } & 1 & $10.3 \pm 1.5$ & $18.7 \pm 6.1$ & $12 \pm 2$ & $10 \pm 0$ & $17.3 \pm 1.2$ & $9.3 \pm 1.2$ & $17.3 \pm 3.8$ & $15.7 \pm 2.3$ & $20 \pm 0$ & $13 \pm 1$ \\
\hline & $1 / 2$ & $7 \pm 1$ & $8 \pm 1$ & 0 & 0 & 0 & $8.3 \pm 0.6$ & $8 \pm 0$ & $8.3 \pm 0.6$ & $8.7 \pm 2.3$ & $7.3 \pm 0.6$ \\
\hline & $1 / 3$ & 0 & 0 & 0 & 0 & 0 & 0 & 0 & 0 & $8.7 \pm 2.3$ & 0 \\
\hline \multirow[t]{3}{*}{ Seraïdi } & 1 & $10.3 \pm 1.5$ & $21 \pm 1$ & $16 \pm 1$ & $14.3 \pm 1.5$ & $12.7 \pm 0.6$ & $8.3 \pm 0.6$ & $16.7 \pm 0.6$ & $20.3 \pm 0.6$ & $13.7 \pm 0.6$ & $17.3 \pm 0.6$ \\
\hline & $1 / 2$ & $7 \pm 1$ & $10 \pm 1$ & $7 \pm 0$ & 0 & 0 & $12 \pm 0$ & $8 \pm 0$ & $10 \pm 0$ & $7.7 \pm 0.6$ & $7.3 \pm 0.6$ \\
\hline & $1 / 3$ & 0 & $8.3 \pm 1.2$ & 0 & 0 & 0 & $10 \pm 0$ & 0 & $7 \pm 0$ & 0 & 0 \\
\hline Oued & 1 & $9 \pm 1$ & $25.3 \pm 6.4$ & $14.3 \pm 1.2$ & $10.7 \pm 0.6$ & $10.7 \pm 1.5$ & $8 \pm 0$ & $22 \pm 0$ & $15 \pm 0$ & $17.3 \pm 0.6$ & $14.7 \pm 0.6$ \\
\hline \multirow[t]{2}{*}{ ElAneb } & $1 / 2$ & 0 & $11.7 \pm 1.5$ & $7 \pm 0$ & 0 & $7 \pm 0$ & $7.3 \pm 2.3$ & $8.3 \pm 0.6$ & $11.3 \pm 1.2$ & $8 \pm 1$ & $7.7 \pm 0.6$ \\
\hline & $1 / 3$ & 0 & $7.3 \pm 0.6$ & 0 & 0 & 0 & 0 & 0 & 0 & $8 \pm 2$ & 0 \\
\hline \multirow[t]{3}{*}{ Laouinet } & 1 & $9.3 \pm 0.6$ & $21.7 \pm 1.5$ & $15.3 \pm 0.6$ & $12.3 \pm 0.6$ & $8 \pm 0$ & $18 \pm 0$ & $17.3 \pm 1.5$ & $19 \pm 2.6$ & $17 \pm 0$ & $40 \pm 0$ \\
\hline & $1 / 2$ & $7 \pm 1$ & $11.3 \pm 0.6$ & $7 \pm 0$ & 0 & 0 & 0 & $7 \pm 0$ & $10 \pm 0$ & $8.3 \pm 2.1$ & $7 \pm 1$ \\
\hline & $1 / 3$ & $7 \pm 1$ & $7 \pm 1$ & 0 & 0 & 0 & 0 & 0 & $7.7 \pm 1.5$ & 0 & 0 \\
\hline \multirow[t]{3}{*}{ ElKhemis } & 1 & $10.7 \pm 0.6$ & $34.3 \pm 1.5$ & $20.7 \pm 2.1$ & $11.3 \pm 0.6$ & $13.3 \pm 2.1$ & $8 \pm 0$ & $33.7 \pm 0.6$ & $27.3 \pm 5.1$ & $20 \pm 0$ & $28 \pm 1.7$ \\
\hline & $1 / 2$ & 0 & $9.3 \pm 1.2$ & $8.3 \pm 0.6$ & 0 & 0 & $7.3 \pm 0.6$ & $9 \pm 1$ & $10.3 \pm 0.6$ & $10 \pm 0$ & $8 \pm 0$ \\
\hline & $1 / 3$ & 0 & $8.7 \pm 1.2$ & $7 \pm 1$ & 0 & 0 & 0 & 0 & 0 & $7.7 \pm 0.5$ & 0 \\
\hline \multirow[t]{3}{*}{ Timdiouan } & 1 & $9.7 \pm 0.6$ & $33 \pm 1$ & $20.7 \pm 2.1$ & $13 \pm 1$ & $10 \pm 0$ & $11 \pm 1$ & $20.7 \pm 5.1$ & $22.7 \pm 3.2$ & $16.7 \pm 0.6$ & $14 \pm 0$ \\
\hline & $1 / 2$ & 0 & $12.3 \pm 0.6$ & $8.7 \pm 0.6$ & $7.5 \pm 0.5$ & $7.5 \pm 0.5$ & $7 \pm 1$ & $9 \pm 0$ & $9 \pm 1$ & $10 \pm 0$ & $7.7 \pm 0.6$ \\
\hline & $1 / 3$ & 0 & $10 \pm 0$ & $7.3 \pm 0.6$ & 0 & 0 & 0 & $7 \pm 0$ & $7.3 \pm 0.6$ & $7.7 \pm 0.6$ & $7.3 \pm 0.6$ \\
\hline \multirow[t]{3}{*}{ Taza } & 1 & $10.7 \pm 1.2$ & $25 \pm 4.4$ & $17 \pm 0$ & $15.3 \pm 1.5$ & $16 \pm 1$ & $9.3 \pm 0.6$ & $19 \pm 3$ & $19 \pm 1.7$ & $25.7 \pm 1.2$ & $26.7 \pm 2.9$ \\
\hline & $1 / 2$ & 0 & $10.7 \pm 1.5$ & $7 \pm 0$ & $7 \pm 0$ & $8 \pm 1.7$ & $8.7 \pm 1.5$ & $8.3 \pm 0.6$ & $9.7 \pm 0.6$ & $9.7 \pm 3.2$ & $7.7 \pm 0.6$ \\
\hline & $1 / 3$ & 0 & $7.3 \pm 0.6$ & 0 & 0 & 0 & 0 & 0 & 0 & $8 \pm 1.7$ & 0 \\
\hline \multirow[t]{3}{*}{ Darguina } & 1 & $7.5 \pm 0.5$ & $24.3 \pm 0.6$ & $20 \pm 0$ & $12.7 \pm 0.6$ & $12.3 \pm 2.5$ & $8.3 \pm 0.6$ & $16 \pm 1$ & $21 \pm 0$ & $22.3 \pm 6.8$ & $21.3 \pm 1.5$ \\
\hline & $1 / 2$ & 0 & $10.7 \pm 1.5$ & $9.3 \pm 0.6$ & $7 \pm 0$ & $7 \pm 0$ & $7 \pm 1$ & $10 \pm 0$ & $10 \pm 2$ & $7.3 \pm 1.2$ & $8 \pm 0$ \\
\hline & $1 / 3$ & 0 & $7.7 \pm 0.6$ & 0 & 0 & 0 & 0 & 0 & $7 \pm 1$ & 0 & 0 \\
\hline Azemour & 1 & $7.3 \pm 0.6$ & $32 \pm 2$ & $18.3 \pm 5$ & $9.3 \pm 0.6$ & $8 \pm 0$ & $8 \pm 0$ & $11 \pm 1.7$ & $21 \pm 2.6$ & $21.3 \pm 1.2$ & $12.7 \pm 0.6$ \\
\hline & $1 / 2$ & 0 & $10 \pm 1$ & $8.7 \pm 0.6$ & 0 & 0 & $7 \pm 0$ & $8 \pm 0$ & $10.3 \pm 0.6$ & $11.3 \pm 1.5$ & $8.7 \pm 0.6$ \\
\hline & $1 / 3$ & 0 & $9 \pm 0$ & $7 \pm 0$ & 0 & 0 & 0 & 0 & $8 \pm 0$ & $8.7 \pm 2.3$ & $7.3 \pm 0.6$ \\
\hline Ibourassen & 1 & $8.3 \pm 0.6$ & $28 \pm 5.3$ & $16 \pm 1.7$ & $15 \pm 1$ & $14.7 \pm 0.6$ & $12 \pm 0$ & $22.7 \pm 1.2$ & $19.3 \pm 0.6$ & $19 \pm 1.7$ & $14.3 \pm 0.6$ \\
\hline & $1 / 2$ & 0 & $10 \pm 0$ & $7.7 \pm 0.6$ & $7.5 \pm 0.5$ & $7.8 \pm 1.9$ & $9 \pm 0$ & $9 \pm 0$ & $10 \pm 0$ & $10 \pm 0$ & $9 \pm 1$ \\
\hline & $1 / 3$ & 0 & $7.7 \pm 0.6$ & 0 & 0 & 0 & $7 \pm 0$ & 0 & 0 & $7.7 \pm 0.6$ & 0 \\
\hline Boulimat & 1 & $15.7 \pm 1.2$ & $30.3 \pm 3.5$ & $22 \pm 0$ & $12.3 \pm 0.6$ & $16 \pm 1$ & $13 \pm 0$ & $16.7 \pm 2.9$ & $20.3 \pm 0.6$ & $27 \pm 1$ & $32.7 \pm 2.3$ \\
\hline & $1 / 2$ & 0 & $10.7 \pm 1.5$ & 0 & $7.7 \pm 0.6$ & $7.3 \pm 0.6$ & $8 \pm 0$ & $8.7 \pm 0.6$ & $8.7 \pm 2.3$ & $9.3 \pm 1.5$ & $7.7 \pm 0.6$ \\
\hline & $1 / 3$ & 0 & $7.3 \pm 0.6$ & 0 & 0 & 0 & 0 & 0 & 0 & $8 \pm 1$ & 0 \\
\hline Beni Ksila & 1 & $12.7 \pm 2.1$ & $11 \pm 2.6$ & $11 \pm 0$ & $11.7 \pm 0.6$ & $13 \pm 1.7$ & $10 \pm 0$ & $11.7 \pm 2.9$ & $14.3 \pm 1.2$ & $21.3 \pm 7.6$ & $14 \pm 1$ \\
\hline & $1 / 2$ & $7 \pm 1$ & $9.3 \pm 1.2$ & $7 \pm 0$ & $7 \pm 0$ & $7.3 \pm 0.6$ & $7.7 \pm 0.6$ & $8.3 \pm 0.6$ & $7.7 \pm 1.5$ & $10.3 \pm 1.5$ & $8 \pm 0$ \\
\hline & $1 / 3$ & 0 & $8 \pm 1$ & 0 & 0 & 0 & 0 & 0 & $7 \pm 1$ & $7.7 \pm 1.5$ & 0 \\
\hline Isoumaten & 1 & $15 \pm 0$ & $21.7 \pm 3.5$ & $24 \pm 1$ & $19.3 \pm 1.2$ & $17.3 \pm 0.6$ & $17.3 \pm 2.5$ & $21 \pm 1$ & $21.3 \pm 1.5$ & $22.3 \pm 6.8$ & $21 \pm 0$ \\
\hline & $1 / 2$ & 0 & $9.7 \pm 1.5$ & $7.3 \pm 0.6$ & $8 \pm 0$ & $8 \pm 1$ & $8.7 \pm 0.6$ & $8.3 \pm 0.6$ & $9 \pm 2$ & $10.3 \pm 1.5$ & $7.7 \pm 0.6$ \\
\hline & $1 / 3$ & 0 & $8.7 \pm 1.5$ & 0 & $7 \pm 0$ & 0 & 0 & $7 \pm 0$ & 0 & 0 & 0 \\
\hline Zemmouri & 1 & $12.3 \pm 2.5$ & $17 \pm 0$ & $10.7 \pm 0.6$ & $13 \pm 1$ & $14.3 \pm 1.2$ & $12.7 \pm 0.6$ & $14.3 \pm 1.2$ & $23.3 \pm 2.9$ & $26 \pm 1$ & $14.7 \pm 0.6$ \\
\hline & $1 / 2$ & 0 & $11 \pm 1.7$ & $8.7 \pm 0.6$ & 0 & 0 & 0 & $8 \pm 0$ & $10.3 \pm 2.1$ & $10 \pm 0$ & $8 \pm 0$ \\
\hline & $1 / 3$ & 0 & $7 \pm 1$ & 0 & 0 & 0 & 0 & 0 & $7 \pm 0$ & $8 \pm 1$ & 0 \\
\hline Talaougouni & 1 & $12.3 \pm 3.1$ & $31 \pm 2.6$ & $23.7 \pm 0.6$ & $19 \pm 1$ & $20 \pm 0$ & $13.7 \pm 0.6$ & $27.3 \pm 2.5$ & $31.3 \pm 4.6$ & $22.6 \pm 0.6$ & $23.7 \pm 2.9$ \\
\hline & $1 / 2$ & 0 & $10.3 \pm 2.9$ & $8.3 \pm 0.6$ & $7.8 \pm 0.3$ & $8 \pm 1$ & $7.7 \pm 0.6$ & $9 \pm 1$ & $12 \pm 1.7$ & $9.3 \pm 0.3$ & $7.3 \pm 0.6$ \\
\hline & $1 / 3$ & 0 & $8 \pm 1$ & 0 & 0 & 0 & 0 & 0 & $8.3 \pm 1.5$ & $7.3 \pm 0.3$ & 0 \\
\hline Hammam & 1 & $13.3 \pm 1.5$ & $22.3 \pm 2.5$ & $16.3 \pm 1.2$ & $15 \pm 0$ & $13 \pm 1$ & $13.7 \pm 1.2$ & $17 \pm 0$ & $15.7 \pm 5.1$ & $23.3 \pm 1.2$ & $22 \pm 0$ \\
\hline Melouan & $1 / 2$ & 0 & $9.3 \pm 1.2$ & $7 \pm 0$ & 0 & $7 \pm 0$ & $7.3 \pm 1.2$ & $8 \pm 0$ & $9 \pm 1.7$ & $9.7 \pm 3.2$ & $8.3 \pm 0.6$ \\
\hline & $1 / 3$ & 0 & $7.3 \pm 1.2$ & 0 & 0 & 0 & 0 & 0 & 0 & $8.7 \pm 0.6$ & 0 \\
\hline Honaïn & 1 & $12.7 \pm 1.2$ & $32.7 \pm 1.2$ & $19.3 \pm 1.2$ & $16.7 \pm 1.5$ & $15 \pm 0$ & $13 \pm 0$ & $21.3 \pm 1.2$ & $25.7 \pm 3.8$ & $27.3 \pm 2.5$ & $23 \pm 0$ \\
\hline & $1 / 2$ & $7 \pm 1$ & $10 \pm 1.7$ & 0 & $7.7 \pm 0.6$ & 0 & $8.3 \pm 2.1$ & $8.7 \pm 0.6$ & $8.3 \pm 2.5$ & $9.7 \pm 2.1$ & $7.3 \pm 0.6$ \\
\hline & $1 / 3$ & $7 \pm 1$ & $7.3 \pm 0.6$ & 0 & 0 & 0 & 0 & 0 & 0 & $7.7 \pm 1.2$ & 0 \\
\hline Gentamicine 3 & $30 \mu \mathrm{g}$ & 21 & 26 & 27 & 0 & 22 & 27 & 22 & 27 & 30 & 25 \\
\hline Imipeneme 10 & & 26 & 20 & 0 & 12 & 14 & 19 & 18 & 23 & 34 & 34 \\
\hline Cefotaxime 30 & $\mu \mathrm{g}$ & 32 & 17 & 0 & 0 & 9 & 29 & 12 & 8 & 18 & 14 \\
\hline Colistine $10 \mu \mathrm{g}$ & & 15 & 11 & 0 & 10 & 9 & 11 & 8 & 10 & 8 & 0 \\
\hline
\end{tabular}


Table 6. Main effects and interactions of essential oils of Myrtus communis

\begin{tabular}{|c|c|c|c|}
\hline Source & df & $\mathbf{F}$ & $\mathbf{P}$ \\
\hline \multicolumn{4}{|l|}{ Main Effects } \\
\hline Sampling location & 18 & 25.17 & $.0000 * * *$ \\
\hline Dilution level & 6 & 10494.62 & $.0000 * * *$ \\
\hline Bacteria Species & 9 & 2402.93 & $.0000 * * *$ \\
\hline \multicolumn{4}{|l|}{ Interaction } \\
\hline Sampling location $*$ Dilution level & 108 & 15.164 & $.0000 * * *$ \\
\hline Sampling location * Bacteria Species & 162 & 4.98 & $.0000 * * *$ \\
\hline Dilution level $*$ Bacteria Species & 54 & 962.17 & $.0000 * * *$ \\
\hline Sampling location $*$ Dilution level $*$ Bacteria Species & 972 & 3.66 & $.0000 * * *$ \\
\hline
\end{tabular}

Note: Very highly significant $(\mathrm{P}<0.001)$

Table 7. The effectiveness of essential oils from different locations against bacteria

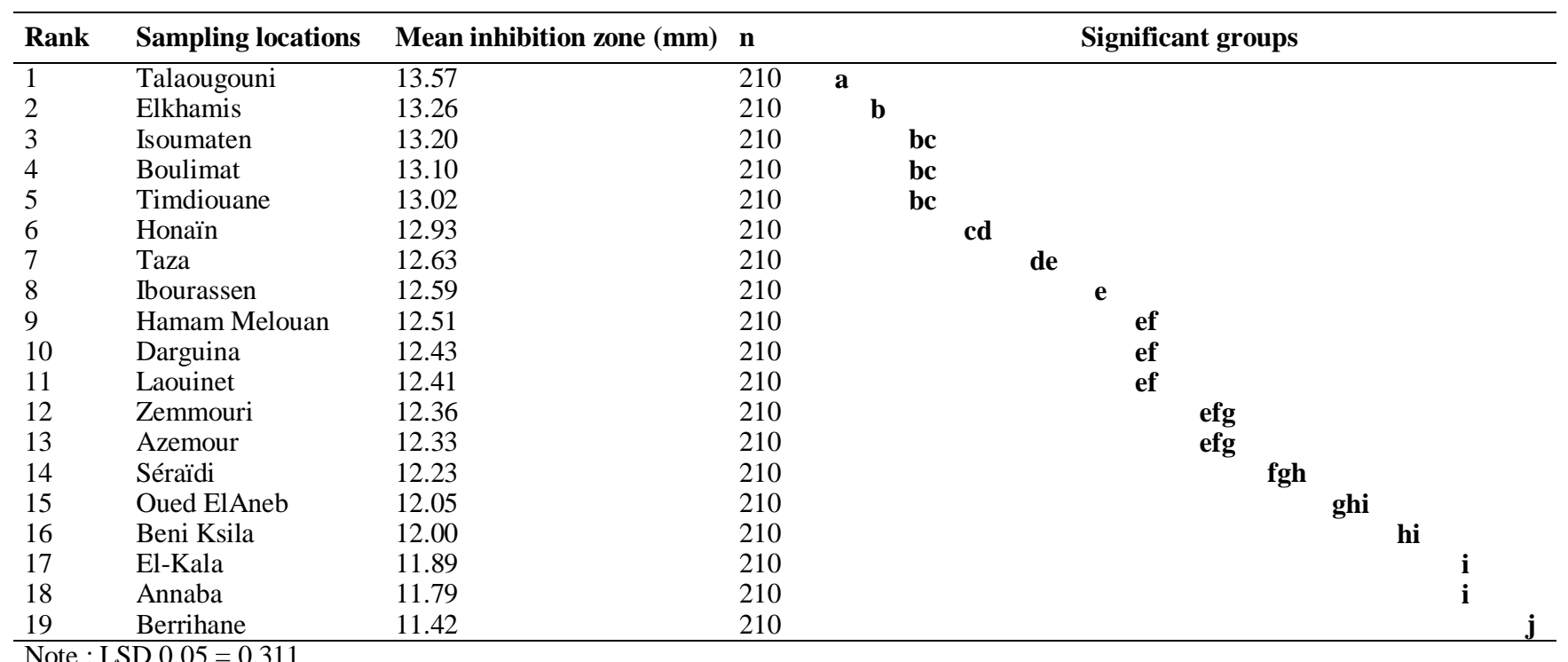

Table 8. The effect of oil dilutions on the inhibitory zone of tested bacteria

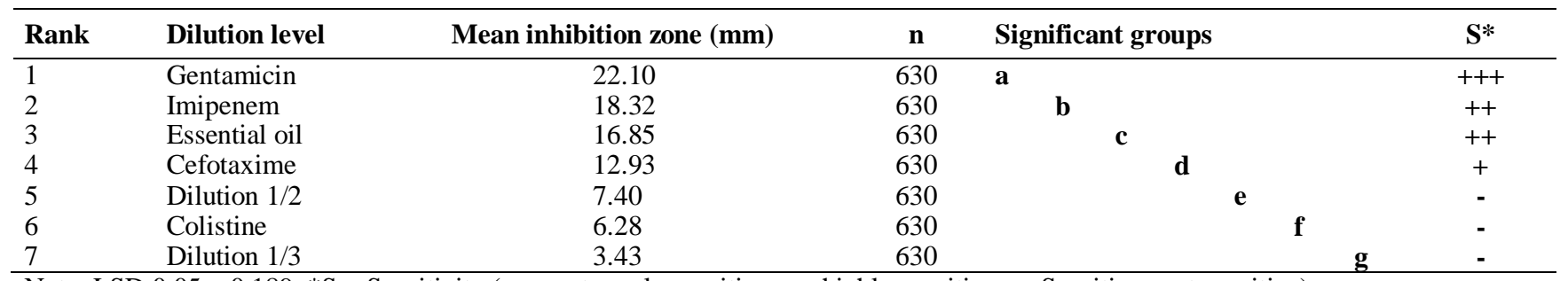

Note: LSD 0.05 = 0.189; *S = Sensitivity (+++ extremely sensitive; ++ highly sensitive; + Sensitive;-not sensitive)

Table 9. Sensitivity groups of the bacteria tested to the essential oils of Myrtus communis

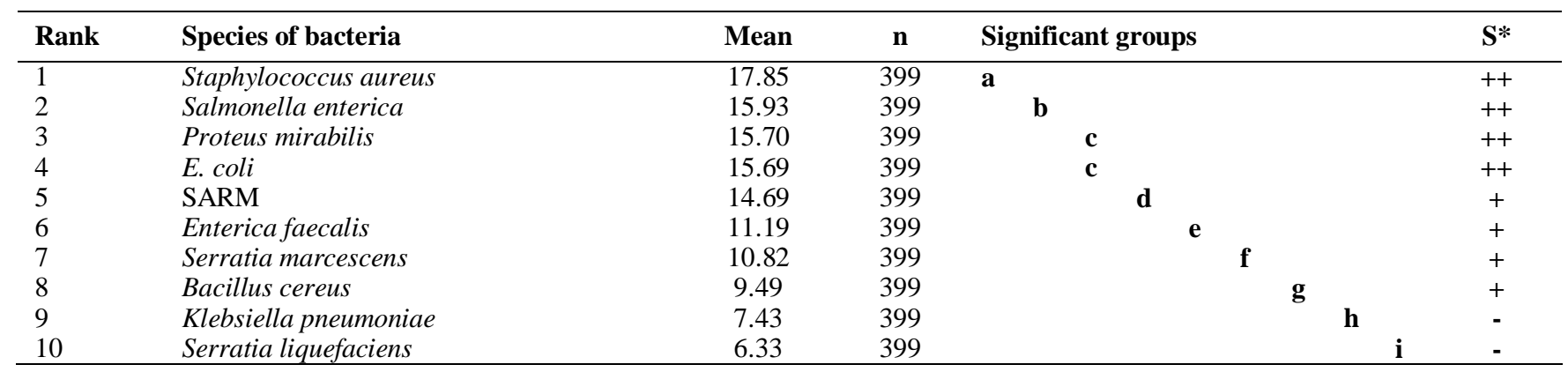

Note: LSD $0.05=0.226$ *S = Sensitivity (+++ extremely sensitive; ++ highly sensitive; + sensitive;-not sensitive) 
Linalool content in this study has an average of $3.79 \pm$ $2.97 \%$, while populations of Tenes (Algeria) contain $23.4 \%$ (Hennia et al. 2015) and Turkey samples contain $28.3 \%$ (Chalchat et al. 1998).

Myrtenyl acetate is an oxygenated monoterpene rarely found in the oils of Algerian myrtle. Touaïbia (2016) obtained that the population of Ain Defla (Algeria) contains myrtenyl acetate of $38.7 \%$. Myrtenyl acetate has been reported from Spain (Boelens et al. 1992), Portugal (Pereira et al. 2009), Albania (Asllani et al. 2000), Montenegro (Mimica dukić et al. 2010), Greece (Gardeli et al. 2008) and Iran (Shahbazian 2018) essential oils of $M$. communis. Its presence also reported in Morocco (Satrani et al. 2006; Cherrat et al. 2014; Fadil et al. 2017), and in Tunisia (Traboulsi et al. 2002; Messaoud et al. 2011),

Myrtenyl acetate is used as the criterion for classifying myrtle oils. Myrtle essential oils are distinguished into three types, i.e., the Moroccan and Balkan types that contain myrtenyl acetate while the Tunisian type does not contain myrtenyl acetate (Bradesi et al. 1997). Franchomme et al. (2001) classify the essential oils of $M$. communis with a concentration of myrtenyl acetate of $21 \%$ in the chemotype of myrtenyl acetate, although the concentration of 1,8-cineole is very high (45\%). Twelve chemotypes have been identified in M. communis (Anwar et al. 2017). The $\alpha$-pinene-1,8-cineole chemotype is the most frequently found in nature; this chemotype is dominant in samples from Morocco (Fadil et al. 2017).

Our results showed that Gram-positive bacteria are more sensitive to $M$. communis oils than Gram-negative bacteria. Zomorodian et al. (2013) and Eliuz et al. (2017) reported similar results. The resistance of gram-negative bacteria is due to the presence of an outer membrane possessing chains of hydrophilic polysaccharides, acting as a barrier against hydrophobic essential oils (Tassou et al. 1995; Mann et al. 2000). Many researchers have hypothesized that the antimicrobial activity of essential oils is due to the deterioration of the cell wall. The chemical constituents of essential oils, particularly the monoterpenes, would increase the permeability of the cytoplasmic membrane by disrupting the order of proteins integrated into the membrane, thus inhibiting cellular respiration, the processes of transport of ions and the absorption of nutrients (Reichling et al., 2009; Amensour et al. 2010).

Antibacterial tests showed that Staphylococcus aureus was the most sensitive bacterium to essential oils of $M$. communis. Many authors have noted an antibacterial activity of the $M$. communis oils against $S$. aureus (Yadegarina et al. 2006; Salvagnini et al. 2008; Akin et al. 2010; Ben Hsouna et al. 2014; Eliuz et al. 2017; Fadil et al. 2017). On the other hand, Aboutabl et al. (2011) and Belmimoun et al. (2016) found no sensitivity of the bacteria with essential oils of M. communis.

The essential oils of $M$. communis have a significant effect against $E$. coli, which is consistent with the literature data (Koukos et al. 2001; Rasooli et al. 2002; Sadiki et al. 2014; Pirbalouti et al. 2014; Fadil et al. 2017). However, other authors report low or no activity against E. coli (Gonuz and Dulger 2004; Salvagnini et al. 2008; Akin et al. 2010; Aboutabl et al. 2011; Eliuz et al. 2017).
The bacterial strain Klebsiella pneumoniae is resistant to the oil of M. communis (Barhouchi et al. 2016; Eliuz et al. 2017), whereas Pirbalouti et al. 2014 and Ben Hsouna et al. 2014 found stronger activities against this bacteria. Our results show that Proteus mirabilis is highly sensitive to essential oils of $M$. communis, while Barhouchi et al. (2016) reported low sensitivity. Enterica faecalis is sensitive to $M$. communis oils (Ben Hsouna et al. 2014; Eliuz et al. 2017), which is confirmed by our results. While Rasooli et al. (2002) found no activity against E. faecalis.

The differences in results between studies are explained by the great disparity in chemical composition, which exists between essential oils of this species. It is recognized that the effectiveness of essential oils against a bacterium depends directly on its active components, the $\alpha$-pinene, 1,8-cineol, $\beta$-pinene and limonene strongly contribute to antibacterial properties of essential oil myrtle (Ebrahimabadi et al. 2016). Randrianarivelo et al. (2009) reported that oxygenated terpenes in general, particularly 1,8-cineole, linalool and $\alpha$-terpineol, have an important role in the antibacterial activity of myrtle, while Carson and Riley (1995)insist the role of linalool. This information was confirmed by several studies (Hendry et al. 2009; Silva et al. 2012; Eduardo et al. 2017).

In conclusion, forty-six chemical compounds have been successfully identified from the essential oils of Myrtus communis from Algeria. It was dominated by monoterpene hydrocarbons. The $\alpha$-pinene, 1,8-cineole, limonene are the major components. Myrtenyl acetate is only found in four populations. Six chemotypes were identified: three chemotypes characterized by $\alpha$-pinene and three types were characterized by myrtenyl acetate. The essential oils of $M$. communis have moderate antibacterial activity against the bacterial species tested. The undiluted essential oil of the population of Talaougouni has the most potent bacterial growth inhibition. Staphylococcus aureus was the most sensitive bacteria to the essential oils of $M$. communis.

\section{ACKNOWLEDGEMENTS}

The study was supported financially by MESRS of Algeria (Project code No. D01N01UN190120200005), and no potential conflicts of interest.

\section{REFERENCES}

Aboutabl EA, Meselhy KM, Elkhreisy EM, Nassar MI, Fawzi R. 2011. Composition and bioactivity of essential oils from leaves and fruits of Myrtus communis and Eugenia supraxillaris (Myrtaceae) grown in Egypt. J Essential Oil Bear Plants 14 (2): 192-200. DOI: 10.1080/0972060X.2011.10643921.

Adams RP. 2007. Identification of essential oil components by gas chromatography/mass spectrometry. Allured Publishing Corporation, Illinois. USA.

Aidi Wannes W, Mhamdi B, Sriti J, Ben Jemia M, Ouchikh O, Hamdaoui G, Kchouk ME, Marzouk B. 2010 Antioxidant activities of the essential oils and methanol extracts from myrtle (Myrtus communis var. italica L.) leaf, stem and flower. Food Chem Toxicol 48(5): 1362-1370. DOI:_10.1016/j.fct.2010.03.002.

Akin M, Aktumse A, Nostro A. 2010. Antibacterial activity and composition of the essential oils of Eucalyptus camaldulensis Dehn. 
and Myrtus communis L. growing in Northern Cyprus. Afr J Biotechnol 9 (4): 531-535.

Alipour G, Dashti S, Hosseinzadeh H. 2014. Review of pharmacological effects of Myrtus communis L. and its active constituents. Phytother Res 28 (8): 1125-1136. DOI: 10.1002/ptr.5122.

Amensour M, Sendra E, Abrini J, Pérez-Alvarez JA, Fernández-López J. 2010. Antioxidant activity and total phenolic compounds of myrtle $\begin{array}{llllll}\text { extracts. CyTA J Food } 8 \text { (2): 95-101. DOI: } & \end{array}$ 10.1080/19476330903161335.

Amira S, Dade M, Schinella G, Ríos JL. 2012. Anti-inflammatory, antioxidant, and apoptotic activities of four plant species used in folk medicine in the Mediterranean basin. Pak J Pharm Sci 25 (1): 65-72.

Anwar S, Crouch RA, Awadh Ali NA, Al-Fatimi MA, Setzer WN, Wessjohann L. 2017. Hierarchical cluster analysis and chemical characterisation of Myrtus communis L. essential oil from Yemen region and its antimicrobial, antioxidant and anti-colorectal adenocarcinoma properties. Nat Prod Res 31 (18): 2158-2163. DOI: 10.1080/14786419.2016.1277346.

Asllani U. 2000. Chemical composition of Albanian myrtle oil (Myrtus communis L.). J Essential oil Res 12 (2): 140-142. DOI 10.1080/10412905.2000.9699481.

Barboni T, Venturini N, Paolini J, Desjobert JM, Chiaramonti N, Costa J. 2010. Characterisation of volatiles and polyphenols for quality assessment of alcoholic beverages prepared from Corsican Myrtus communis L. berries. Food Chem 122 (4): 1304-1312. DOI: 10.1016/j.foodchem.2010.03.087.

Barhouchi B, Saoudi A, Akila A. 2016. Essential oil chemical composition of myrtle growing in northeastern Algeria and estimation of its antibacterial effectiveness. Amer J Biochem Biotech 12 (2): 110-121. DOI: 10.4314/jfas.v8i2.22.

Bekhechi C, Watheq Malti CE, Boussaïd M, Achouri I, Belilet K, Gibernau M, Casanova J, Tomi F. 2019. Composition and chemical variability of Myrtus communis leaf oil from northwestern Algeria. Nat Prod Commun 5 (10): 1662-1689. DOI 10.1177/1934578X19850030.

Belmimoun A, Meddah B, Meddah ATT, Sonnet P. 2016. Antibacterial and antioxidant activities of the essential oils and phenolic extracts of Myrtus communis and Zygophyllum album from Algeria. J Fundam Appl Sci 8(2): 510-524. DOI: 10.4314/jfas.v8i2.22.

Ben Ghnaya A, Chograni H, Messoud C, Boussaid M. 2013. Comparative chemical composition and antibacterial activities of Myrtus communis L. essential oils isolated from Tunisian and Algerian population. Plant Pathol Microbiol 4 (7): 186. DOI:10.4172/2157-7471.1000186.

Ben Hsouna A, Hamdib N, Miladid R and Abdelkafi S. 2014. Myrtus communis essential oil: chemical composition and antimicrobial activities against food spoilage pathogens. Verlag Helvetica Chimica Acta AG, Zürich. Chem Biodiv 11 (4): 571-80. DOI: 10.1002/cbdv.201300153.

Benchikh F, Benabdallah H, Dahamna S, Khennouf S, Flamini G, Amira S. 2016. Antimotility and antidiarrhoeal activity of Myrtus communis L. leaves essential oil in mice. Intl J Pharmacogn Phytochem Res 8 (7): 1238-1244.

Berka-Zougali B, Ferhat MA, Hassani A, Chemat F, Allaf KS. 2012. Comparative study of essential oils extracted from Algerian Myrtus communis $\mathrm{L}$. leaves using microwaves and hydrodistillation. Intl $\mathrm{J}$ Mol Sci 13: 4673-4695. DOI: 10.3390/ijms13044673.

Berka-Zougali B, Hassani A, Besombes C, Allaf K. 2010. Extraction of essential oils from Algerian myrtle leaves using instant controlled pressure drop technology. J Chromatogr 1217: 6134-6142. DOI: 10.1016/j.chroma.2010.07.080.

Bettaieb A, Darej C, Moujahed N. 2016. Myrtle (Myrtus communis) essential oil effect on in vitro ruminal fermentation of a diet based on ray-grass and concentrate. Options Méditerranéennes A 115: 543-548.

Boelens MH, Jimenez R. 1991. The chemical composition of Spanish myrtle oils, Part I. J Essent Oil Res 3 (3): 173-177. DOI: 10.1080/10412905.1991.9700498.

Boelens MH, Jimenez R. 1992. The chemical composition of Spanish myrtle oils, Part II. J Essential Oil Res 4 (4): 349-353. DOI: 10.1080/10412905.1992.9698084.

Bouzabata A, Boussaha F, Casanova J, Tomi F. 2010. Composition and chemical variability of leaf oil of Myrtus communis from northeastern Algeria. Nat Prod Commun 5 (10): 1659-1662. DOI: 10.1177/1934578X1000501029.

Bouzabata A, Castola V, Bighelli A, Abed L, Casanova J, Tomi F. 2013. Chemical variability of Algerian Myrtus communis L. Chem and Biodiv 10 (1): 129-137. DOI: 10.1002/cbdv.201200150.
Brada M, Tabti N, Boutoumi H, Wathelet JP, Lognay G. 2012. Composition of the essential oil of leaves and berries of Algerian myrtle (Myrtus communis L.). J Essent Oil Res 24 (1): 1-3. DOI: 10.1080/10412905.2012.645299.

Bradesi P, Tomi F, Casanova J, Costa J, Bernardini AF. 1997. Chemical composition of myrtle leaf essential oil from Corsica (France). J $\begin{array}{lllll}\text { Essent Oil Res } 9 \text { (3): 283-288. DOI: } & \end{array}$ 10.1080/10412905.1997.10554245.

Cannas S, Molicotti P, Ruggeri M, Cubeddu M, Sanguinetti M, Arongiu BM, Zanetti S. 2013. Antimycotic activity of Myrtus communis L. towards Candida spp. from clinical isolates. J Infect Dev Ctries 7 (3): 295-298. DOI: 10.1080/14786419.2014.925892.

Carson CF, Riley TV. 1995. Antimicrobial activity of the major components of the essential oil of Melaleuca alternifolia. J Appl Bacteriol 78(3): 264-269.

Chalchat JC, Garry RP, Michet A. 1998. Essential oils of Myrtle (Myrtus communis L.) of the Mediterranean littoral. J Essent Oil Res 10(6): 613-617. DOI: 10.1080/10412905.1998.9700988.

Cherrat L, Espina L, Bakkali M, García-Gonzalo D, Pagán R, Laglaoui A. 2014. Chemical composition and antioxidant properties of Laurus nobilis L. and Myrtus communis L. essential oils from Morocco and evaluation of their antimicrobial activity acting alone or in combined processes for food preservation. J Sci Food Agric 94 (6): 1197-1204. DOI 10.1002/jsfa.6397.

Cox SD, Mann CM, Markham JL, Bell HC, Gustafson JE, Warmington JR, Wyllie SG. 2001. The mode of antimicrobial action of the essential oil of Melaleuca alternifolia (tea tree oil) Journal of Applied Microbiology $88 \quad$ (1): 170-175. DOI: 10.1046/j.13652672.2000.00943.x.

Dahiya P, Purkayastha S. 2012. Phytochemical screening and antimicrobial activity of some medicinal plants against multi-drug resistant bacteria from clinical isolates. Indian J Pharm Sci 74 (5): 443-450. DOI: 10.4103/0250-474X.108420

Deriu A, Branca G, Molicotti P, Pintore G, Chessa M. 2007. In vitro activity of essential oil of Myrtus communis L. against Helicobacter pylori. Intl J Antimicrob Agents 30 (6): 562-563. DOI: 10.1016/j.ijantimicag.2007.07.005.

Ebrahimabadi EH, Ghoreishi SM, Masoum S, Ebrahimabadi AH. 2016. Combination of $\mathrm{GC} / \mathrm{FID} / \mathrm{mass}$ spectrometry fingerprints and multivariate calibration techniques for recognition of antimicrobial constituents of Myrtus communis L. essential oil. J Chromatogr B Analyt Technol Biomed Life Sci 1008: 50-57. DOI: 10.1016/j.jchromb.2015.11.010.

Eduardo L, Farias T, Silva G, Lopes F, Ferreira S. 2017. Antibacterial potential of the alpha-pinene positive enantiomer against the strain Proteus mirabilis. Conference: MOL2NET 2017, International Conference on Multidisciplinary Sciences, 3rd ed. DOI : 10.3390/mol2net-03-04935.

Eliuz Erdogan A, Ayas D, Goksen G. 2017. In vitro phototoxicity and antimicrobial activity of volatile oil obtained from some aromatic plants. J Essent Oil Bearing Plants 20 (3): 758-768. DOI: 10.1080/0972060X.2017.1331141

Fadil M, Farah A, Bouchaib I, Haloui T, Lebrazi S, Rachiq S. 2017. Intrapopulation variability of Myrtus communis L. growing in Morocco: Chemometric investigation and antibacterial activity. J Appl Res Med Aromatic Pl 7: 35-40. DOI: 10.1016/j.jarmap.2017.04.006.

Foudil-Cherif Y, Boutarene N, Yassaa N. 2013. Chemical composition of essential oils of Algerian Myrtus communis L. and chiral analysis of their leaf volatiles. J Essent Oil Res 25 (5): 401-407. DOI: 10.1080/10412905.2013.828323.

Franceschini P. 2016. Myrtus communis L. en Corse et en Méditerranée : De sa composition chimique jusqu'à ses utilisations thérapeutiques. Thèse de doctorat, Université Victor Segalen Bordeaux 2, U.F.R. des Sciences Pharmaceutiques, France. [French]

Franchomme P, Pénoël D, Jollois R. 2001. L'aromathérapie exactement. Encyclopédie de l'utilisation thérapeutique des huiles essentielles. Edit Roger Jollois, France. [French

Gardeli C, Vassiliki P, Athanasios M, Kibouris T, Komaitis M. 2008. Essential oil composition of Pistacia lentiscus L. and Myrtus communis L.: Evaluation of antioxidant capacity of methanolic extracts. Food Chem 107 (3): 1120-1130. DOI: 10.1016/j.foodchem.2007.09.036.

Gonuz A and Dulger B. 2004. Antimicrobial activity of certain plants used in Turkish traditional medicine. Asian J Plant Sci 3 (1): 104-107. DOI: 10.3923/ajps.2004.104.107. 
Hayder N, Kilani S, Abdelwahed A, Mahmoud A, Meftahi K, Chibani JB, Ghedira K, Chekir-Ghedira L. 2003. Antimutagenic activity of aqueous extracts and essential oil isolated from Myrtus communis. Pharmazie 58 (7): 523-524

Hendry ER, Worthington T, Conway BR, Lambert PA. 2009 Antimicrobial efficacy of eucalyptus oil and 1,8-cineole alone and in combination with chlorhexidine digluconate against microorganisms grown in planktonic and biofilm cultures. J Antimicrob Chemother. 64 (6): 1219-1225. DOI : 10.1093/jac/dkp362.

Hennia A, Brada M, Nemmiche S, Fauconnier ML, et Lognay G. 2015 Chemical composition and antibacterial activitiy of the essential oils of Algerian Myrtus communis L. J Essent Oil Res 27 (4): 324-328. DOI: $10.1080 / 10412905.2015 .1023905$.

Hennia A, Graça Miguel M, Nemmiche S. 2018. Antioxidant activity of Myrtus communis L. and Myrtus nivellei Batt. \& Trab. extracts: a brief review. Medicines 5 (89): 1-68. DOI: 10.3390/medicines5030089.

Hosseinzadeh H, Khoshdel M, Ghorbani M. 2011. Antinociceptive, antiinflammatory effects and acute toxicity of aqueous and ethanolic extracts of Myrtus communis L. aerial parts in mice. J Acupunct. Meridian Stud 4 (4): 242-247. DOI: 10.1016/j.jams.2011.09.015.

Koukos PK, Papadopoulou KI, Papagiannopoulos AD, Patiaka D. 2001. Chemicals from Greek forestry biomass: Constituents of the leaf oil of Myrtus communis L. grown in Greece. J Essent Oil Res 13 (4): 245-246. DOI: 10.1080/10412905.2001.9699683.

Mann CM, Cox SD, Markham JL. 2000. The outer membrane of Pseudomonas aeruginosa NCTC6749 contributes to its tolerance to the essential oil of Melaleuca alternifolia (tea tree oil). Lett Appl Microbiol 30 (4): 294-297. DOI: 10.1046/j.1472-765x.2000.00712.x.

Masada Y. 1976. Analysis of essential oils by gas chromatography and mass spectrometry. John Wiley \& Sons, New York.

Messaoud C, Afif M, Boulila A, Rejeb MN, Boussaid M. 2007. Genetic variation of Tunisian Myrtus communis L. (Myrtaceae) populations assessed by isozymes and RAPDs. Ann For Sci 64: 845-853.

Messaoud C, Béjaoui A, Boussaid M. 2011. Fruit color, chemical and genetic diversity and structure of Myrtus communis L. var. italica Mill. morph populations. Biochem Syst Ecol 39(4-6): 570-580. DOI: 10.1016/j.bse.2011.08.008

Migliore J, Baumel A, Juin M, Médail F. 2012. From Mediterranean shores to central Saharan mountains: Key phylogeographical insights from the genus Myrtus. J Biogeogr 39: 942-956. DOI: 10.1111/j.1365-2699.2011.02646.x

Mimica-Dukic N, Bugarin D, Grbovic S, Mitić-Ćulafić D, Vuković-Gačić B, Orčić D, Jovin E and Couladis M. 2010. Essential oil of Myrtus communis $\mathrm{L}$. as a potential antioxidant and antimutagenic agents. Molecules 15 (4): 2759-2770. DOI: 10.3390/molecules15042759.

NIST. 2002. Mass spectral search program for the NIST/EPA/NIH Mass spectral library, vers. 2.0. fiveash data, USA.

Onal S, Timur S, Okutucu B, Zihnioğlu F. 2005. Inhibition of alphaglucosidase by aqueous extracts of some potent antidiabetic medicinal herbs. Prep Biochem Biotechnol 35 (1): 29-36. DOI: 10.1081/PB 200041438.

Pereira PC, Cebola MJ, Bernardo-Gil MG. 2009. Evolution of the yields and composition of essential oil from portuguese myrtle (Myrtus communis L.) through the vegetative cycle. Molecules 14 (8): 3094 3105. DOI: $10.3390 /$ molecules14083094.

Pirbalouti AG, Hamedi B, Mehravar L, Firouznejhad M. 2014. Diversity in chemical composition and antibacterial activity of the essential oils of wild populations of myrtle from natural habitats in southwestern Iran. Indian J Trad Knowl 13 (3): 484-489.

Ponce AG, Fritz R, Del Valle C, Roura SI. 2003. Antimicrobial activity of essential oils on the native microflora of organic Swiss chard. Lebensmittel-Wissenschaft und Technologie 36 (7): 679-684. DOI: 10.1016/S0023-6438 (03)00088-4

Quézel P and Santa S. 1962. Nouvelle flore de l'Algérie et des régions désertiques méridionales. Ed CNRS, Paris, France. [French]

Randrianarivelo R, Sarter S, Odoux E, Brat P, Lebrun M, Romestand B, Menut C, Andrianoelisoa HS, Raherimandimby M, Danthu P. 2009. Composition and antimicrobial activity of essential oils of Cinnamosma fragrans. Food Chem 114: 680-684. DOI: 10.1016/j.foodchem.2008.10.007

Rasooli I, Moosavi ML, Rezaee MB, Jaimand K. 2002. Susceptibility of Microorganisms to Myrtus communis L. essential oil and its chemical composition. J Agric Sci Technol 4 (3): 127-133. DOI 10.1.1.1020.6099.
Reichling J, Schnitzler P, Suschke U and Saller R. 2009. Essential oils of aromatic plants with antibacterial, antifungal, antiviral, and cytotoxic properties-an overview. Forsch Komplementmed 16: 79-90. DOI: 10.1159/000207196.

Rossi A, Di Paola R, Mazzon E, Genovese T, Caminiti R, Bramanti P, Pergola C, Koeberle A, Werz O, Sautebin L and Cuzzocrea S. 2009. Myrtucommulone from Myrtus communis exhibits potent antiInflammatory effectiveness in Vivo. J Pharmacol Exp Therapeut 329 (1): 76-86. DOI: 10.1124 /jpet.108.143214

Sacchetti G, Muzzoli M, Statti GA, Conforti F, Bianchi A, Agrimonti C, Ballero M, Poli F. 2007. Intra-specific biodiversity of Italian myrtle (Myrtus communis L.) through chemical markers profile and biological activities of leaf methanolic extracts. Nat Prod Res 21 (2): 167-179. DOI: 10.1080/14786410600603783.

Sadiki M, Balouiri M, Barkai H, Maataoui H, Ibnsoud Koraichi S, Elabed S. 2014. Synergistic antibacterial effect of Myrtus communis and Thymus vulgaris essential oils fractional inhibitory concentration index. Intl J Pharm Pharmaceut Sci 6 (6): 121-124.

Salimi Beni A, Kocheki Shahmokhtar M, Masoumias A, Khajehsharifi H. 2017. Phytochemical and biological studies of some myrtus (Myrtus communis L.) populations of southwest region of Zagros (Iran). Nat Prod Chem Res 5 (7): 290, DOI: 10.4172/2329-6836.1000290.

Salvagnini LE, Oliveira JRS, Dos Santos LE, Moreira RR, Pietro RCLR. 2008. Evaluation of the antibacterial activity of Myrtus communis L. (Myrtaceae) leaves. Revista Brasileira de Farmacognosia 18 (2): 241244. DOI: $10.1590 / \mathrm{S} 0102-695 X 2008000200018$.

Satrani B, Farahe A, Talbi M. 2006. Effet de la distillation fractionnée sur la composition chimique et l'activité antimicrobienne des huiles essentielles du Myrte (Myrtus communis L.) du Maroc. Acta Bot Gallica 53 (2): 235-242. DOI: 10.1080/12538078.2006.10515539.

Schuh G, Heiden AC, Hoffmann T, Kahl J, Rockel P, Rudolph J and Wildt J. 1997. Emissions of volatile organic compounds from sunflower and beech: dependence on temperature and light intensity. J Atmos Chem 27: 291-318. DOI: 10.1023/A:1005850710257.

Shahbazian D, Karami A, Eshghi S, Maggi F. 2018. Variation in the essential oil yields and compositions of Myrtle (Myrtus communis L.) populations collected from natural habitats of Southern Iran. J Essent Oil Res 30 (5): 369-378. DOI: 10.1080/10412905.2018.1486745.

Shoshtari ZV, Rahimmalek M, Sabzalian MR, Hosseini H. 2017. Essential oil and bioactive compounds variation in myrtle (Myrtus communis L.) as affected by seasonal variation and salt stress. Chem Biodivers 14 (4): DOI: $10.1002 / \mathrm{cbdv} .201600365$.

Silva A, Lopes P, Azevedo M, Costa D, Alviano C, Alviano D. 2012. Biological Activities of $\alpha$-pinene and $\beta$-pinene Enantiomers. Molecules (Basel, Switzerland) 17 (6): 6305-6316. DOI : 10.3390/molecules 17066305

Sissay M and Gashaw T. 2017. Ethnobotanical, ethnopharmacological, and phytochemical studies of Myrtus communis L.: a popular herb in Unani system of medicine. J Evid Based Compl Altern Med 22: 1035-1043. DOI: $10.1177 / 2156587217718958$.

Sumbul S, Aftab Ahmad M, Asif M, Akhtar M. 2011. Myrtus communis Linn. A review. Indian J Nat Prod Res 2 (4): 395-402.

Tassou CC, Nychas GJE. 1995. Antimicrobial activity of the essential oil of Mastic gum (Pistacia lentiscus var. chia) on gram-positive and gram-negative bacteria in broth and model food systems. Intl Biodeter Biodegrad 36 (3-4) : 411-420. DOI: 10.1016/0964-8305(95)00103-4.

Touaibia M. 2016. Chemical composition and anti-inflammatory activity of Myrtus communis L. essential oil. Algerian J Arid Environ 6 (2): 73-82. DOI: $10.12816 / 0046166$

Traboulsi AF, Taoubi K, El-Haj S, Bessiere JM, Rammal S. 2002. Insecticidal properties of essential plant oils against the mosquito Culex pipiens molestus (Diptera: Culicidae) Pest Manag Sci 58 (5): 491-495. DOI: $10.1002 / p s .486$

Tuberoso CIG, Barra A, Angioni A, Sarritzu E, Pirisi FM. 2006. Chemical composition of volatiles in Sardinian myrtle (Myrtus communis L.) alcoholic extracts and essential oils. J Agric Food Chem 54 (4): 14201430. DOI: $10.1021 /$ jf052425g

Yadegarinia D, Gachkar L, Rezaei MB, Taghizadeh M, Astaneh SA, Rasooli I. 2006. Biochemical activities of Iranian Mentha piperita L. and Myrtus communis L. essential oils. Phytochemistry 67 (12): 12491255. DOI: 10.1016/j.phytochem.2006.04.025.

Zomorodian K, Moein M, Lori ZG, Ghasemi Y, Rahimi MJ, Bandegani A, Pakshir K, Bazargani A, Mirzamohammadi S, Abbasi N. 2013. Chemical composition and antimicrobial activities of the essential oil from Myrtus communis leaves. J Ess Oil Bearing Plants 16(1): 76-84. DOI: 10.1080/0972060X.2013.764183. 